


\section{THE HEALTH AND WELL-BEING OF Ioung Children of Immigrants}




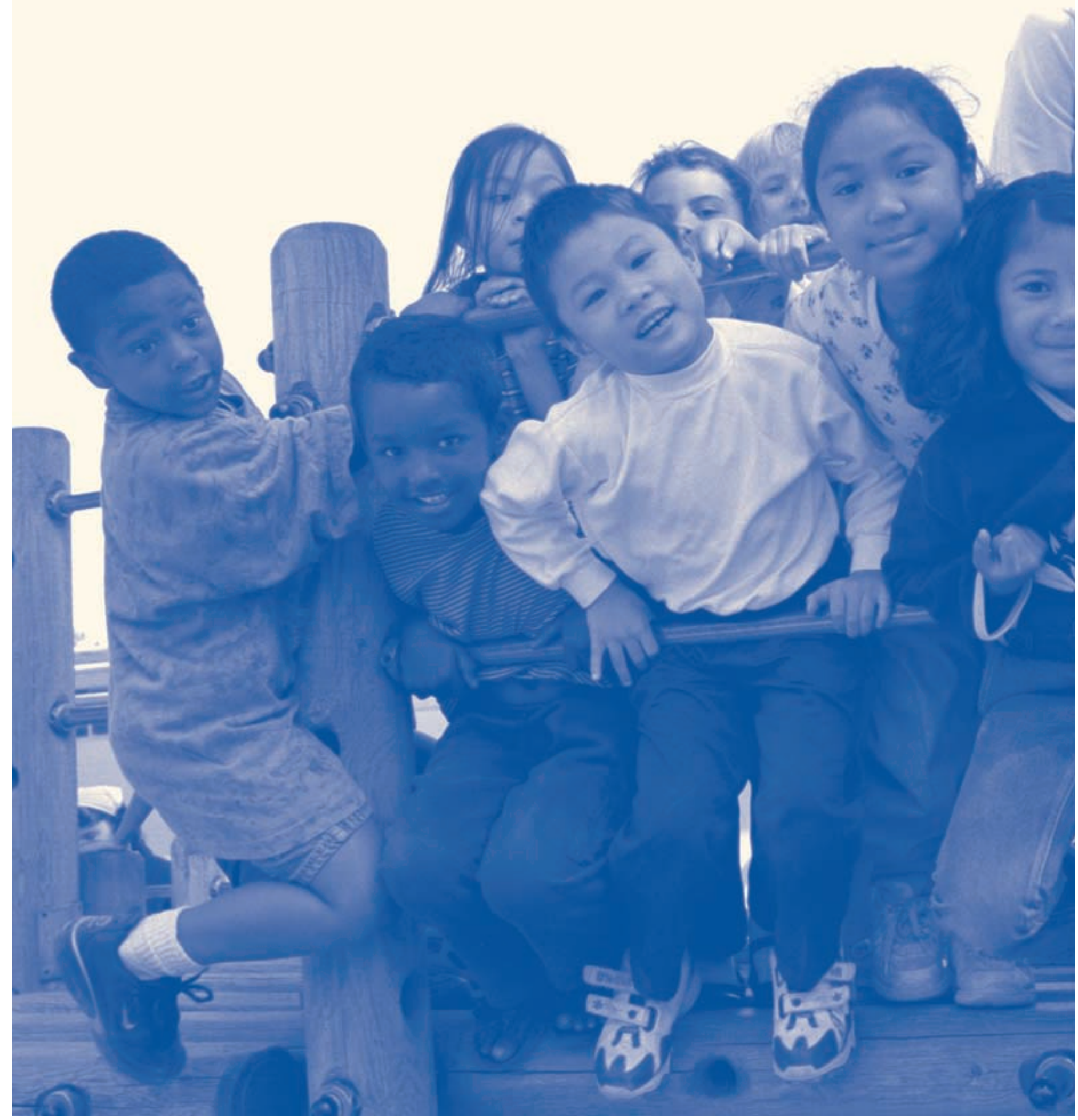




\title{
THE HEALTH AND WELL-BEING OF
}

Young Children of Immigrants

\author{
Randy Capps
}

Michael Fix

Jason Ost

Jane Reardon-Anderson

Jeffrey S. Passel 
This report was made possible by generous financial support from the Foundation for Child Development. Additional support was provided by the Annie E. Casey Foundation.

\section{Cover photograph (C) Susie Fitzhugh.}

Copyright (C) 2004. The Urban Institute. All rights reserved. Except for short quotes, no part of this book may be reproduced or used in any form or by any means, electronic or mechanical, including photocopying, recording, or by information storage or retrieval system, without written permission from the Urban Institute.

The Urban Institute is a nonprofit, nonpartisan policy research and educational organization that examines the social, economic, and governance problems facing the nation. The views expressed are those of the authors and should not be attributed to the Urban Institute, its trustees, or its funders. 


\section{CONTENTS}

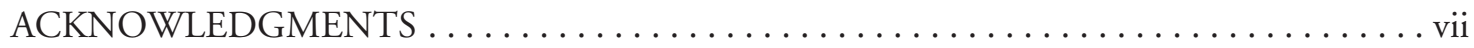

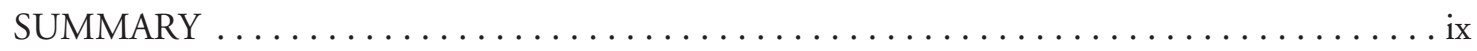

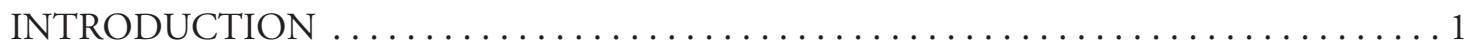

IMMIGRATION TRENDS AND IMPACTS

Over One-Fifth of Young Children Have Immigrant Parents $\ldots \ldots \ldots \ldots \ldots \ldots \ldots \ldots$

Two-Thirds Live in Six States . . . . . . . . . . . . . . . . . . . . . . . 5

Most Are Citizens, Many Have Undocumented Parents . . . . . . . . . . . . 6

Half of Parents Are Recent Arrivals. ............................ 8

Half of Immigrant Children and Two-Thirds of Immigrant Parents Were Born

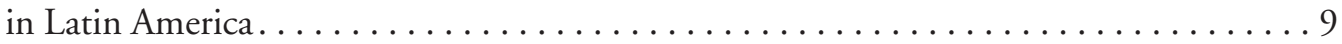

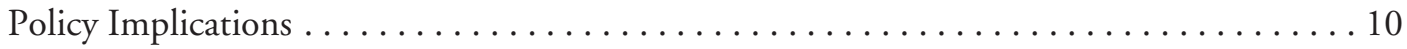

POVERTY, FAMILY STRUCTURE, AND PARENTS' WORK

Poverty Rates Higher among Children of Immigrants $\ldots \ldots \ldots \ldots \ldots \ldots \ldots \ldots \ldots$

Children of Immigrants More Likely to Be in Two-Parent Families . . . . . . . . . . 12

Immigrant Families Less Likely to Have Two Working Parents. . . . . . . . . . . . . . . 13

Wages Lower for Immigrant Parents. . . . . . . . . . . . . . . . . . . 16

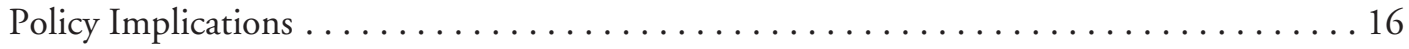

RISK FACTORS FOR POOR SCHOOL PERFORMANCE

AMONG YOUNG CHILDREN OF IMMIGRANTS

Three in Ten Children of Immigrants Have Parents without a High School Degree . . . . . . 17

Six in Ten Have Limited English Proficient Parents. . . . . . . . . . . . . . . . . 18

One-Third Live in Linguistically Isolated Households $\ldots \ldots \ldots \ldots \ldots \ldots \ldots \ldots \ldots$

Parent-Child Interaction Lower in Immigrant Families . . . . . . . . . . . . . . . . . 19

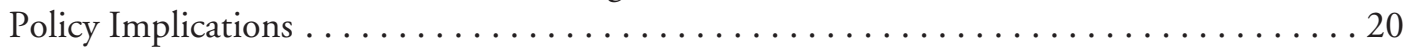

HARDSHIP AND BENEFIT USE AMONG YOUNG CHILDREN

OF IMMIGRANTS

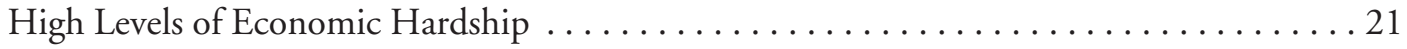

Children of Immigrants Less Likely to Receive Public Benefits . . . . . . . . . . . . . 22

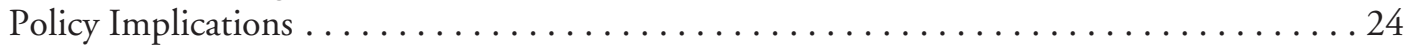




\section{HEALTH STATUS AND INSURANCE COVERAGE}

Children of Immigrants Twice as Likely to Be in Fair or Poor Health and

Lack a Usual Source of Care................................. 25

Twice as Likely to Be Uninsured, but Rate Falls from 1999 to 2002 . . . . . . . . . . . . 26

Policy Implications . . . . . . . . . . . . . . . . . . . . . . . . . 28

\section{CHILD CARE ARRANGEMENTS}

Young Children of Immigrants Less Likely to Be in Child Care. . . . . . . . . . . . . . . 29

Gap in Child Care Narrows for Children with Working Parents . . . . . . . . . . . . 30

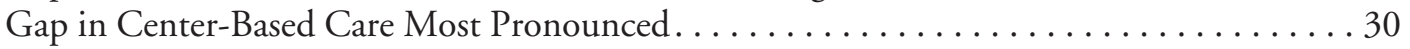

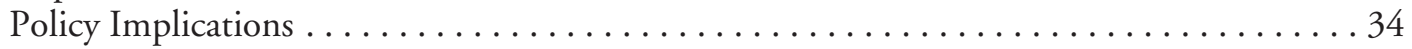

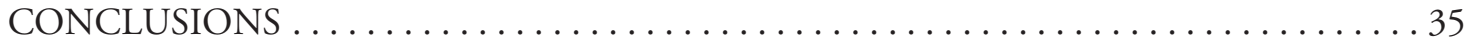

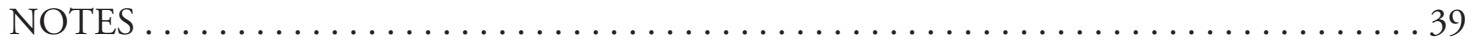

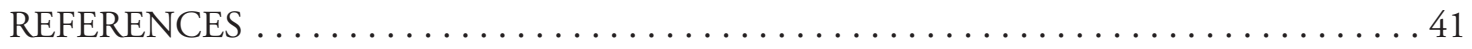

FIGURES

1. Dispersal of Children of Immigrants under 6 across the United States, 1990-2000 . . . . . 6

2. Distribution by Legal Status of Young Children of Immigrants and Their Parents, $2002 \ldots 7$

3. Distribution by Duration of Parents' Residence for Young Children of Immigrants, $2002 \ldots 8$

4. Regions of Birth for Immigrant Parents of Children under 6, $2002 \ldots \ldots \ldots \ldots \ldots \ldots \ldots$

5. Low-Income and Poverty Rates for Children by Age, $2002 \ldots \ldots \ldots \ldots \ldots \ldots \ldots \ldots \ldots$

6. Share of Children in Two-Parent Families, 2002 ......................... 12

7. Family Structure for Low-Income Children under 6, 2002 . . . . . . . . . . . . . . 13

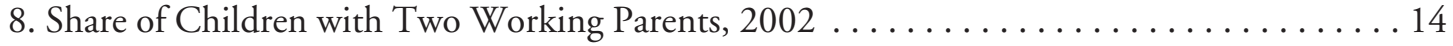

9. Low-Income and Poverty Rates for Young Children by Family Structure, 2002 . . . . . . . 14

10. Low-Income and Poverty Rates for Young Children in Two-Parent Families

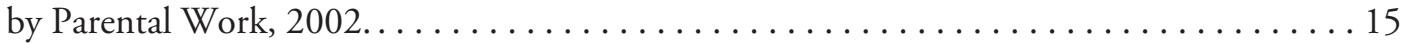

11. Median Hourly Wage Earned by Higher-Earning Parent, $2001 \ldots \ldots \ldots \ldots \ldots \ldots \ldots \ldots$

12. Distribution of Children under 6 by Parents' Education Levels, 2002 . . . . . . . . . . . . 17

13. Share of Children under 6 with Limited English Proficient Parents, 2000 . . . . . . . . . 18

14. Share of Children under 6 in Linguistically Isolated Households, 2000 . . . . . . . . . . . . 19

15. Interaction with Parents for Children under 6, $2002 \ldots \ldots \ldots \ldots \ldots \ldots \ldots \ldots$

16. Food and Housing Hardship Rates for Children under $6,2002 \ldots \ldots \ldots \ldots \ldots \ldots \ldots . \ldots \ldots$

17. Food and Housing Hardship Rates for Low-Income Children under 6, 2002 . . . . . . . . 22

18. Share of Low-Income Children under 6 Receiving Public Benefits, 2002 . . . . . . . . . . 23

19. Share of Children in Fair or Poor Health or without a Usual Source of Health Care, 2002 . 25

20. Share of Children under 6 without Health Insurance, 1999 and 2002 . . . . . . . . . 26

21. Share of Low-Income Children under 6 without Health Insurance, 1999 and 2002 . . . . 27

22. Share of Low-Income Children under 6 with Public Health Insurance Coverage,

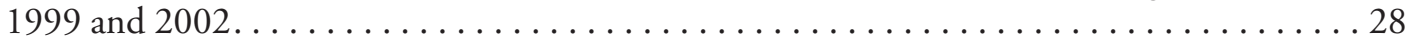

23. Share of Low-Income Children under 6 in Center-Based Child Care, 2002 . . . . . . . . . . 31

24. Share of Children under 6 in Center-Based Child Care by Family Structure and

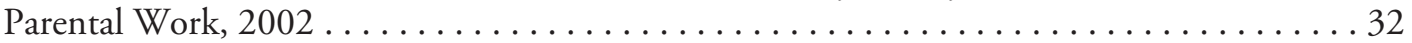

25. Share of Children in Center-Based Child Care by Age, 2002 . . . . . . . . . . . . . . . 32

26. Share of Children under 6 in Center-Based Care by Parents' Educational

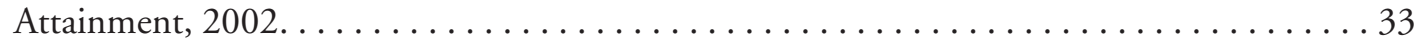

\section{TABLES}

1. Child Care Arrangements for Children under 6, 2002 . . . . . . . . . . . . . . . . 29

2. Child Care Arrangements for Children under 6 with Working Parents, 2002 . . . . . . . 30 


\section{ACKNOWLEDGMENTS}

The authors would like to acknowledge Ruby Takanishi and Annette Chin at the Foundation for Child Development for their guidance and insight in the development and writing of this report. Gina Adams and Jeff Capizzano at the Urban Institute provided critical guidance for framing and discussing the issues in the child care section of the report. We would also like to thank Mark Greenberg and colleagues at the Center on Law and Social Policy for their helpful comments. Donald Hernandez at the State University of New York, Albany provided a thorough review of the document, particularly the section on poverty and family structure. Harold Leibowitz at the Foundation for Child Development also reviewed the document and provided many useful suggestions for the summary. Fiona Blackshaw of the Urban Institute ably edited and oversaw production of this report. We thank Susie Fitzhugh for the use of her photograph, which was originally taken for the Annie E. Casey Foundation's Making Connections-White Center. 



\section{SU M M ARY}

This report focuses on the health and well-being of young children under 6 in immigrant families, those with at least one parent born outside the United States. Eight key themes emerge from the research:

1. Children of immigrants are a large share of the young child population. Children of immigrants are the fastest growing component of the child population (Hernandez 1999). While immigrants are 11 percent of the total U.S. population, children of immigrants make up 22 percent of the 23.4 million children under 6 in the United States. They make up a larger share of the population under 6 than the population age 6 to 17 (20 percent). Policies, then, that advantage or disadvantage younger children — such as child care and early education-will have farreaching impacts on children of immigrants. Correlatively, policies affecting young children and their families will increasingly be judged by their effects on the health, well-being, and school readiness of children of immigrants.

2. Most young children of immigrants are citizens living in mixed-status families. Almost all (93 percent) children of immigrants under 6 are citizens. Most live in mixed-status families with one or more noncitizen parents. These legal and illegal noncitizen parents may be reluctant to approach public or publicly funded institutions for services despite their children's citizenship and eligibility (Fix and Zimmermann 1999). As a result, children of immigrants use public benefits less often than children of natives, despite higher rates of economic hardship.

3. Over one-quarter of young children of immigrants have undocumented parents. Twentynine percent of children of immigrants under 6 live in families with one or more undocumented parents. No matter how Congress resolves the current debate over providing legal status for undocumented immigrants, the results will have a major impact on large numbers of immigrant families with young children.

4. More young children of immigrants than natives live in two-parent families. Children of immigrants under 6 are more likely to live in two-parent families than natives ( 86 versus 75 percent). They are also more likely to live in two-parent families with low incomes (50 versus 26 percent), but less likely to live in families with two working parents ( 43 versus 50 percent).

5. Many young children of immigrants live in families with low incomes, have parents with low education levels and limited English proficiency, and interact less often with their parents. All these factors are associated with low performance in school.

- Fifty-six percent of young children of immigrants live in low-income families (families with incomes less than twice the federal poverty level); 64 percent of foreign-born children of immigrants live in low-income families. 
Twenty-nine percent of young children of immigrants have parents with less than a high school education (versus 8 percent of children of natives).

- Fifty-eight percent have one or more limited English proficient (LEP) parents.

- Seventy-four percent of young children of immigrants are read to by parents at least three times a week, compared with 89 percent of children of natives.

6. Young children of immigrants have higher levels of economic hardship but lower use of benefits than children of natives. Children of immigrants are substantially more likely to be poor and to experience food- and housing-related hardship. Fifty-six percent of young children of immigrants are low-income versus 40 percent of young children of natives. At the same time, low-income children of natives under 6 are twice as likely to receive Food Stamps and more than twice as likely to receive Temporary Assistance for Needy Families (TANF) as young low-income children of immigrants.

One explanation for lower levels of public benefit use is that many young noncitizen children are ineligible for federal means-tested public benefit programs like TANF, food stamps, and Medicaid. Almost half of young noncitizen children are undocumented and are, as a result, ineligible for virtually all benefits except emergency Medicaid. At the same time, legal noncitizen children are also ineligible for TANF and Medicaid in most states. Moreover, many eligible citizen children with noncitizen parents do not participate in these programs because the parents are unaware that their children are eligible or afraid of the consequences of benefit receipt for their legal status and citizenship (Rodriguez, Hagan, and Capps 2004). Because TANF is often the gateway to other benefits, children of immigrants may also be excluded from such work supports as child care subsidies.

7. Children of immigrants are more likely to have fair or poor health and to lack health insurance or a usual source of health care. Young low-income children of immigrants remain twice as likely to be uninsured as those of natives ( 22 versus 11 percent), despite a substantial increase in the coverage of low-income children of immigrants through Medicaid and other public programs between 1999 and 2002 (from 45 to 57 percent). Seven percent of young children of immigrants are reported in fair or poor health by their parents, over twice the rate for children of natives (3 percent). More than twice as many young children of immigrants as natives lack a usual source of health care (8 versus 3 percent).

8. Children of immigrants are more often in parental care and less often in center-based child care. Children of immigrants under 6 are more likely to receive child care from parents ( 53 versus 34 percent for children of natives) and less likely to be in center-based care (17 versus 26 percent). Use of center-based care is lowest among children of immigrants whose parents have little education. These differences in use can be partially explained by family structure, low incomes, patterns of work participation, and, perhaps, by differing propensity for care (Capizzano and Adams 2003). Access issues such as cost, lack of subsidies, language barriers, and availability of nearby care may also be associated with lower use of center-based care. While our data show lower participation in centerbased care among children of immigrants, little is known about the reasons for these patterns (Takanishi 2004). When only families with two working parents are considered, however, the gap between children of immigrants and natives narrows somewhat.

Child care, especially in center-based settings, may benefit a child's early development and socialization and ease the transition from home to school (NICHD Early Child Care Research Network 2000). Child care may also help children of immigrants adapt to a new culture and language, and overcome linguistic isolation and other barriers (Brandon 2004). At the same time, child care centers can be institutions that provide adult education, improve parenting skills, increase family access to health care and other benefits, and link parents to the communities in which they live. 


\section{INTRODUCTION}

Why have we prepared this profile of the children of immigrants under age 6? One reason is the simple force of numbers. According to the 2000 Census, roughly one in five young children in the United States is the child of an immigrant; one in four low-income children (children living in families with incomes below 200 percent of the federal poverty level) is the child of an immigrant (Fix, Zimmermann, and Passel 2001). Children of immigrants are the fastest growing segment of the nation's child population (Hernandez 1999). By the year 2020, we estimate that almost 30 percent of all children in the United States will have one or more foreign-born parents.

A second reason for our profile is that comparatively little is known about this population. It has been noted that research has focused more attention on immigrant adults than on the children of immigrants (Fuligni and Yoshikawa 2003). Recent demographic studies have profiled the young child population age 5 and under in California (Reed and Bailey 2002), children of immigrants under 18 (National Center for Children in Poverty 2002), and the use of center-based child care by children of immigrants (Brandon 2004), but no study of which we are aware has examined national trends among children of immigrants age 5 and under.

Third, as we demonstrate here, the young children of immigrants differ in some important ways from immigrant children more generally. These differences stem from the fact that young children of immigrants are more likely to be born in the United States and to be citizens living in what we term mixed-status families (Fix and Zimmermann 1999). Citizenship is, of course, an important protective factor for young children, since citizenship entitles them to receive public benefits and services on the same terms as children of natives.

At the same time, though, young children of immigrants are more likely than older children to be born into families with younger parents who arrived in the United States relatively recently. Many immigrant parents of young children have comparatively little formal schooling, limited English skills, and low incomes. Many are undocumented, and comparatively few are naturalized citizens. Many legal noncitizen parents with young children have lived in the United States less than five years and are ineligible for federal public benefits - as are the small share of their children who are foreignborn. All these characteristics represent potential risk factors in child development. But here again, we find important protective factors in place. Young children of immigrants are more likely to live in two-parent families than children of natives, especially low-income children.

Another imperative for our work is the importance of the early years in child development. As a rapidly growing body of scholarship has pointed out, the neurochemistry of the brain develops during early childhood at a pace that far exceeds any other stage of life (National Research Council and Institute of Medicine [NRC and IOM] 2000). As Deborah Phillips (2001) has written, the centrality of early childhood to development places a premium on early experiences and environment. She notes, 
If these early experiences are positive, normal development proceeds. If they are neglectful and deprive children of stimulation, development is compromised. In this sense every early environment is an early intervention, whether we call it Head Start or child care.

\section{Our Definition of Children of Immigrants}

Throughout this report we define "young children" as those under age 6, and "children of immigrants" as those living with at least one parent born outside the United States. ${ }^{1}$ Some of these children live with a single foreign-born parent, some with two foreign-born parents, and others with one parent born in the United States and the other born in another country. Children of natives are those living with a single parent who is U.S.-born or with two U.S.-born parents. In some analyses, we also disaggregate children who are themselves born outside the United States, although they are a small fraction of all young children of immigrants.

\section{Data Sources}

The data for our analyses are drawn from three sources: the 2000 U.S. Census of Population and Housing 1 Percent Sample (Census), the 2002 U.S. Current Population Survey (CPS), and the Urban Institute's 2002 National Survey of America's Families (NSAF). We occasionally use the 1999 NSAF to show trends over time where they appear to be significant.

We use these three data sources because they include a wide range of important measures for our profile. The Census, for instance, is the only source that includes information on English proficiency. The Current Population Survey contains data we use to assign legal status to noncitizens in the sample. The National Survey of America's Families includes more extensive information on health, hardship, and child care than the other two data sets.

\section{Organization of the Report}

The report is divided into six broad sections. The first provides an overview of immigration trends and their effects on the composition of the young child population. This section describes young children of immigrants in terms of their citizenship, legal status, and countries of origin. Here we highlight the fact that although many of these children have noncitizen—even undocumented-parents, most were themselves born in the United States.

The second section discusses poverty, family structure, and parental work patterns. Most children of immigrants have a second parent in the home, yet children of immigrants in two-parent families are substantially more likely to be poor than children of natives with two parents. One important factor is the lower wages paid to immigrant parents.

The third section of the report explores the educational attainment and English proficiency of immigrant parents, and their potential effect on children's school performance. Many children of immigrants live in linguistically isolated households where no one over the age of 14 speaks English very well-putting them at risk for higher poverty and lower achievement in school. Additionally, parent-child interaction is lower in immigrant families than in native families.

The fourth section examines hardship rates and benefits receipt. Children of immigrants tend to have relatively high levels of poverty, difficulty affording food, housing hardship, and fair or poor 
physical health. Yet children in immigrant families are also less likely to receive government assistance in the form of welfare, food stamps, housing subsidies, or health insurance coverage.

The fifth section analyzes health status and health insurance coverage. Young children of immigrants are more than twice as likely to be reported in fair or poor health than young children in native families. Their health insurance coverage through public sources-Medicaid and the State Children's Health Insurance Program (SCHIP) — however, has been improving (Capps, Kenney, and Fix 2003).

We devote the final section of the report to child care arrangements; here we report our child care findings for children age under age 3 and those age 3 to 5 . In both age groups, children of immigrants are significantly less likely to have a formal child care arrangement outside the home, although the gap between children of immigrants and natives narrows when both parents work. We also find a substantial gap between children of immigrants and those of natives in the use of center-based care. 



\section{IMMIGRATION TRENDS AND IMPACTS}

\section{Over One-Fifth of Young Children Have Immigrant Parents}

As a result of rapid recent immigration, children with immigrant parents compose a large and rising share of the nation's young child population. More than 13 million immigrants entered the United States during the 1990s, up from 10 million in the 1980s and 7 million in the 1970s. Data from 2000 through 2003 suggest that 14 million more immigrants will enter the country in this decade (2000-09). The foreign-born share of the total U.S. population has risen dramatically, from 5 percent in 1970 to more than 12 percent in 2003. Between 1990 and 2000, the number of children of immigrants under 6 grew by 60 percent nationally, from 3 to 4.7 million. ${ }^{2}$

Although immigrants are 12 percent of the total U.S. population, children of immigrants make up 22 percent of the 23.4 million children under 6 in the United States. Children of immigrants are a larger share of the child population under 6 (22 percent) than they are of the age 6 to 17 population (20 percent).

\section{Two-Thirds Live in Six States}

Children of immigrants are highly concentrated in six "major destination" states, but they are dispersing rapidly to many others. According to the Census, in 2000 about two-thirds (68 percent) of the total population of young children of immigrants lived in the six largest states highlighted in figure 1 with a diagonal pattern (California, Texas, New York, Florida, Illinois, and New Jersey). In 1990, almost three-quarters (74 percent) of young children of immigrants lived in these same six states. Increasing dispersal of immigrant families to other states accounted for the falling share of all young children of immigrants in these six major destination states between 1990 and 2000.

Ten states (shaded dark blue in figure 1) had especially rapid growth in their populations of young children of immigrants between 1990 and 2000. In order of growth rates, they are North Carolina (270 percent), Nebraska (269 percent), Arkansas (244 percent), Nevada (236 percent), Georgia (210 percent), Iowa (182 percent), Tennessee (165 percent), Oregon (159 percent), Colorado (155 percent), and Idaho (152 percent). These states form three clusters-across the Southeast, the central Great Plains, and the western Rocky Mountains. The population of young children also grew rapidly - by more than 80 percent - in 13 other states in the same regions (these states are shaded medium blue in figure 1). Both groups of states had growth rates faster than Texas (76 percent) — the fastest growing of the six major destination states.

Rapid growth in the population of young children of immigrants across the country means that issues related to their health, well-being, education, and integration are no longer concerns for just a handful of 
FIGURE 1. Dispersal of Children of Immigrants under 6 across the United States, 1990-2000

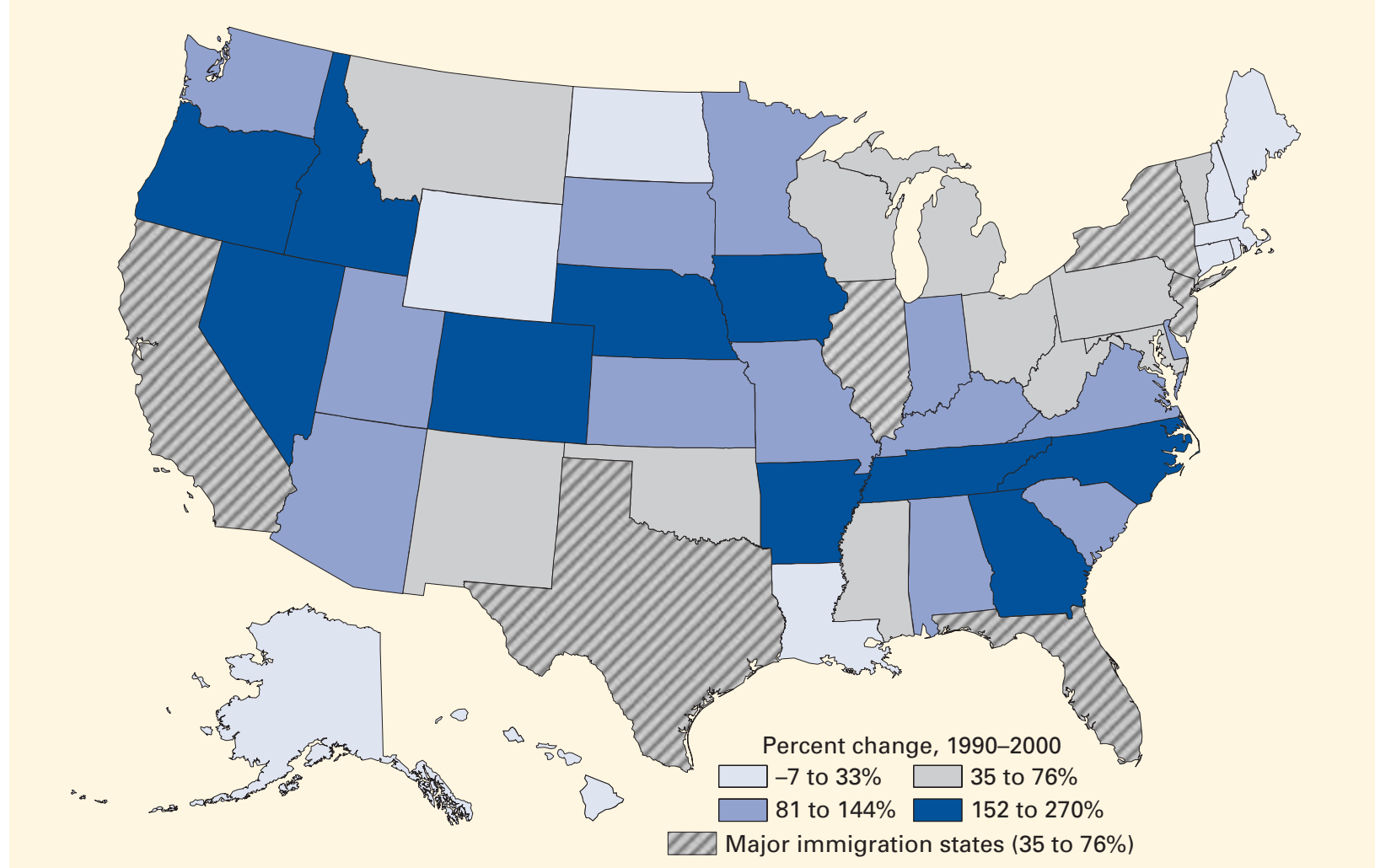

Sources: 1990 and 2000 U.S. Censuses of Population and Housing, Integrated Public Use Microdata Sample.

major states and cities (Capps, Fix, and Passel 2002). The issues discussed in this report affect children throughout the country, although these populations and issues are very new in many communities.

\section{Most Are Citizens, Many Have Undocumented Parents}

The typical immigrant family is a mixed-status family that includes adults who are noncitizens and young children who are U.S.-born citizens (Fix and Zimmermann 1999). Because they are mostly citizens, children in mixed-status families are more likely to have full legal and social membership in the United States than their parents, who are often noncitizens.

Mixed-status families are more common among younger children than older children. Sixteen percent of all children under 6 in the United States live in mixed-status families, compared with 11 percent of all children 6 to 17. The vast majority of children under 6 in immigrant families (93 percent) are U.S.-born citizens. In contrast, only 77 percent of children age 6 to 17 in immigrant families are citizens.

Eighty-one percent of young children of immigrants have a noncitizen parent. In general, it takes five years before a legal immigrant can apply to become a citizen; immigrants who marry citizens can 
apply after three years. In many cases, young children's parents have not resided in the United States long enough to become citizens.

\section{Many Have Undocumented Parents}

Almost 30 percent of young children of immigrants have an undocumented parent. ${ }^{3}$ Most undocumented immigrants do not and will not qualify for citizenship or legal permanent residency unless current immigration law changes. Undocumented parents are ineligible for most public benefits and may be wary of asking for assistance owing to fears of deportation and other immigration consequences. Young children with undocumented parents are particularly vulnerable, since their parents are generally low-income and ineligible for assistance. By putting currently undocumented immigrants on the path to legal status and citizenship, legalization proposals could eventually extend eligibility for public benefits to some noncitizen parents and expand the social support available to their young children. ${ }^{4}$

\section{Younger Children More Likely to Be Citizens}

Younger children of immigrants (under age 6 ) are more likely to be U.S. citizens than older children (6 to 17), as shown in figure 2. Only 7 percent of younger children are noncitizens, compared with 22 percent of older children. Roughly half of both older and younger noncitizen children are themselves undocumented. Nonetheless, a far higher share of older than younger children are undocumented (12 versus 3 percent).

FIGURE 2. Distribution by Legal Status of Young Children of Immigrants and Their Parents, 2002

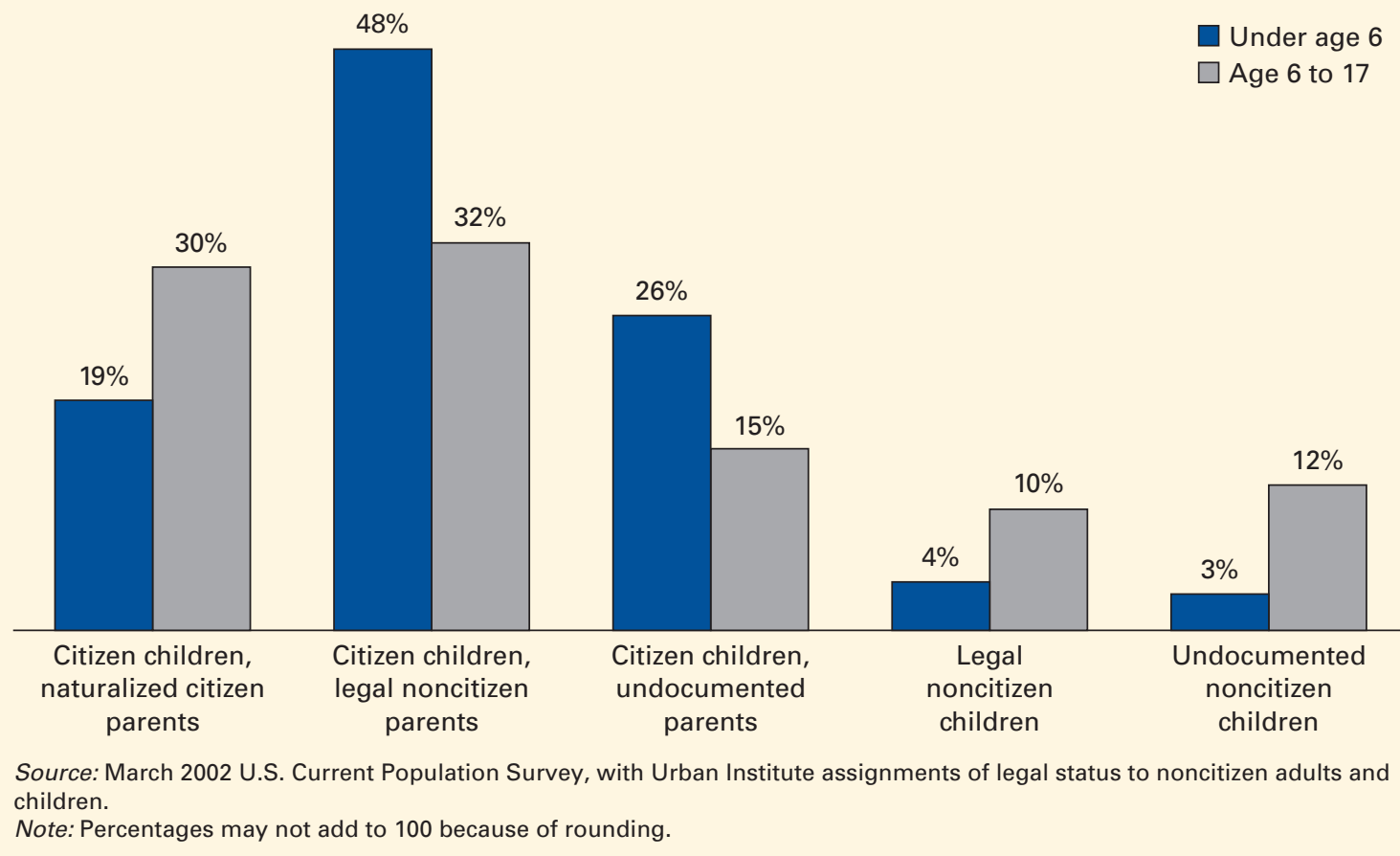


A higher share of older children of immigrants are citizens with naturalized parents (30 versus 19 percent). The parents of older children are more likely to have naturalized, in part because they have been in the country longer. Younger children are more likely to have parents who are legal noncitizens or undocumented.

These distinctions are important when considering eligibility for and participation in public assistance programs. Three-quarters of young children of immigrants are in mixed-status families. In these families, the children are eligible for public benefits and services, while many parents are not. A significantly higher share of older children are themselves ineligible for public benefits.

\section{Half of Parents Are Recent Arrivals}

In 2002, about half of the parents in immigrant families with young children had arrived in the United States within the past 10 years (i.e., since 1992), a fifth within the last five years (i.e., since 1997). Younger children were almost twice as likely as older children to have parents who entered the country during the previous five years or within the past 10 years (figure 3).

Since eligibility for many federally funded public benefits (for instance, Temporary Assistance for Needy Families, Food Stamps, and Medicaid) is restricted to legal immigrants who have been in the country five years or longer, a substantial share of immigrant parents with young children are ineligible for these benefits. ${ }^{5}$ Additionally, many legal immigrants who entered the United States in December 1997 or later may be subject to sponsor deeming provisions, which require the income of immigrants' sponsors to be counted toward eligibility for these federally funded programs. These provisions often disqualify legal immigrants for benefits by pushing family incomes over the eligibility limits of means-tested programs.

FIGURE 3. Distribution by Duration of Parents' Residence for Young Children of Immigrants, 2002

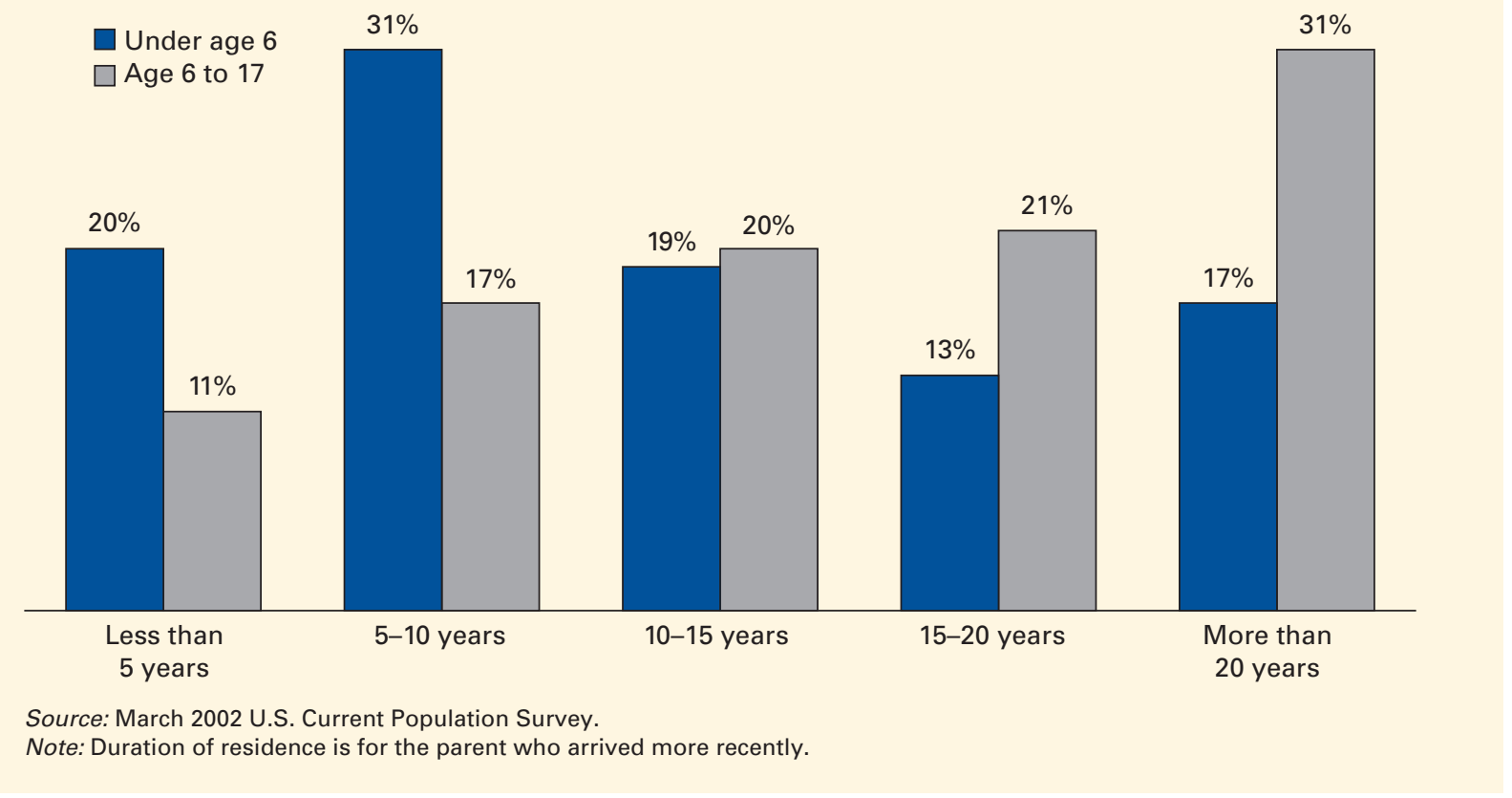


Recency of arrival is correlated with lower ages and incomes, less education, and poorer English skills among immigrant adults. These parent characteristics may make younger children of immigrants more vulnerable in terms of economic hardship and school performance.

\section{Half of Immigrant Children and Two-Thirds of Immigrant Parents Were Born in Latin America}

Most children of immigrants under 6 (86 percent) have only foreign-born parents. The total number of foreign-born parents with young children was 5.9 million in 2002. One in seven young children in immigrant families has one parent born in the United States and one born outside the country.

Nearly two-thirds of foreign-born parents with young children were born in Latin America (figure 4). Mexico is the most common country of birth for these parents (39 percent); other Latin American countries account for another 25 percent. Lower shares of parents were born in Asia (23 percent) and Europe or Canada (7 percent).

Except for Canada, all of the 10 most common countries of origin for immigrants with young children are considerably less affluent than the United States. ${ }^{6}$ In many instances, undocumented migrants make up a sizeable share of the immigration flow from these countries.

FIGURE 4. Regions of Birth for Immigrant Parents of Children under 6, 2002

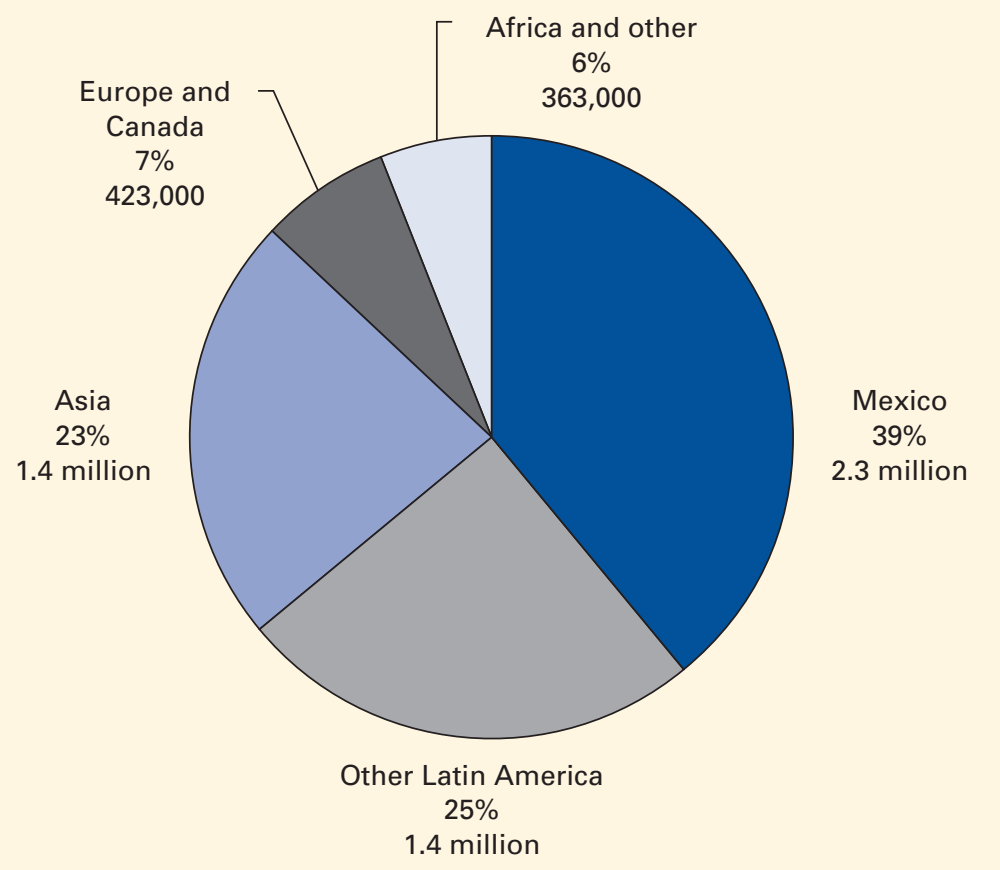

Source: March 2002 U.S. Current Population Survey.

Note: Numbers represent numbers of parents by their region of birth. 


\section{Policy Implications}

Since children of immigrants are such a large share of young children, policies that advantage or disadvantage younger children — child care and early education, for example—will have farreaching effects on children of immigrants. Correlatively, policies affecting young children and their families will increasingly be judged by their effects on the health, well-being, and school readiness of children of immigrants.

Most children of immigrants live in mixed-status families, in which the children are U.S. citizens but one or more parents is a noncitizen. In these families, the children may be eligible for public benefits and services, but their parents might not, owing to restrictions on noncitizen eligibility. It is also likely that noncitizen parents — whether legal or illegal immigrants - may fear interaction with government agencies owing to concerns about deportation, denial of citizenship applications, or other immigration-related consequences (Fix and Zimmermann 1999).

These fears and concerns may be particularly acute for families with undocumented immigrants. Over one-quarter (29 percent) of children of immigrants under age 6 have at least one undocumented parent. Undocumented immigrants often have low-paying jobs without access to such benefits as health insurance. Although proposals to legalize undocumented immigrants would not affect most children of immigrants directly (since 93 percent are U.S. citizens), they could strongly affect the economic and social trajectories of many of their parents, as well as their willingness to apply for benefits for their citizen children.

The population of immigrants and their children is growing most rapidly in areas of the country with little experience in immigrant integration. States in rapidly growing regions like the Midwest and Southeast may be encountering large immigrant populations for the first time in decades. The presence of these new arrivals may be felt by new demands on health care, social services, and education systems by children of immigrants. 


\section{POVERTY, FAMILY STRUCTURE, AND PARENTS' WORK}

\section{Poverty Rates Higher among Children of Immigrants}

Poverty is one of the most important predictors of negative child outcomes (NRC and IOM 1999). Poverty rates are generally higher among children of immigrants than among children of natives, and highest for young children of immigrants. Over a quarter of young children in immigrant families are poor, compared with a fifth in native families (figure 5 ). Over half (56 percent) of young children of immigrants have low incomes, compared with 40 percent of young children of natives. Among older children of immigrants, 23 percent are poor; 52 percent have low incomes.

\section{Poverty Rates Highest among Noncitizen Children}

Although they represent only 7 percent of all young children of immigrants, foreign-born children under age 6 are more likely to live in low-income families. Sixty-three percent of young foreign-born

FIGURE 5. Low-Income and Poverty Rates for Children by Age, 2002

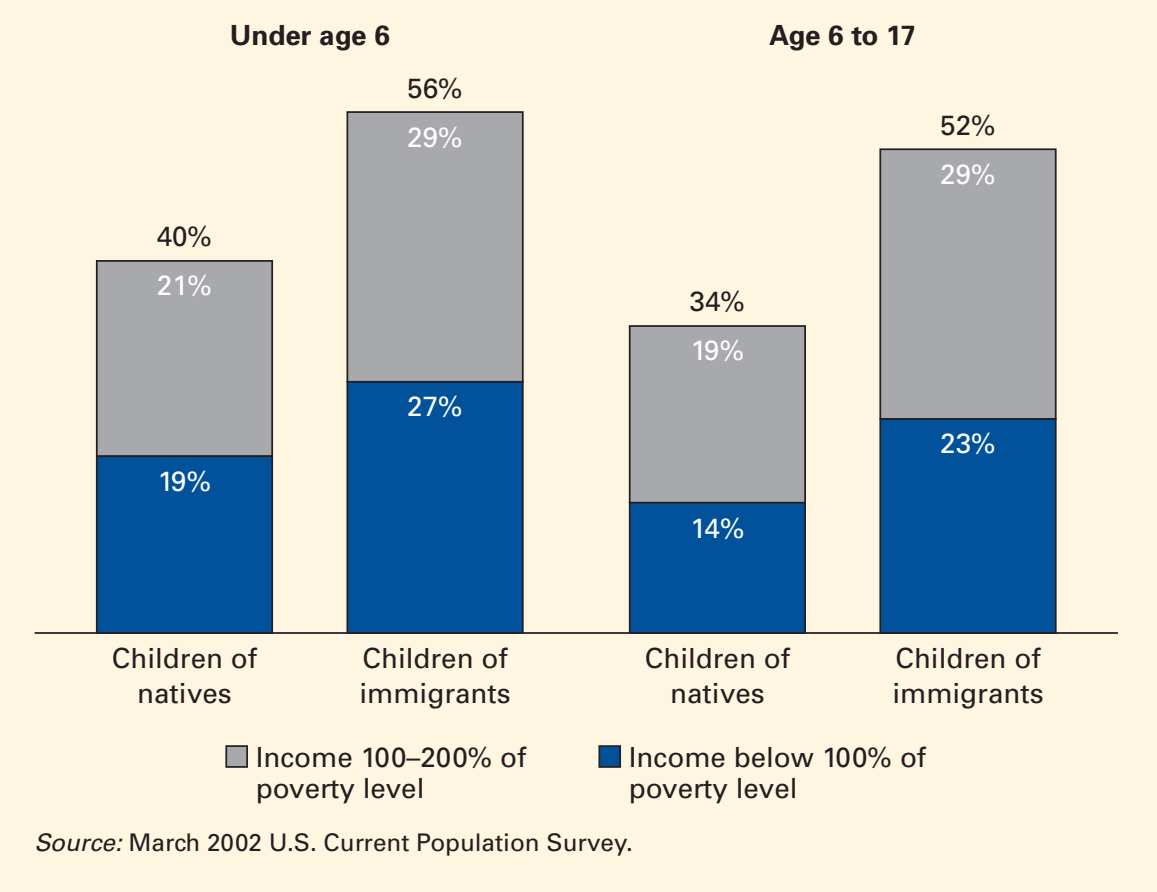


children are low income, compared with 56 percent of all children with immigrant parents. Foreignborn children are virtually all noncitizens, and are therefore much less likely to be eligible for meanstested federal benefits such as TANF, food stamps, Medicaid, and SCHIP. They are also less likely to be eligible for child care and other support services that are largely restricted to TANF recipients. About half of foreign-born children are undocumented and therefore ineligible for virtually all public benefits except emergency Medicaid. The balance is mostly legal immigrants who are eligible for food stamps but ineligible for federally funded TANF, Medicaid, and SCHIP, because they have been in the country for less than five years. However, some states - most notably California-provide similar benefits for legal immigrants regardless of when they entered the United States (Zimmermann and Tumlin 1999).

\section{Reasons for High Poverty among Young Children of Immigrants}

There are two main reasons young children in immigrant families have higher poverty rates than children in native families. First, although children of immigrants are more likely to be in two-parent families, the second parent in these families is less likely to work, a pattern that is largely explained by lower labor force participation among immigrant women. Second, immigrants earn lower wages, leading to lower family incomes (Hernandez 2004). Low educational attainment and limited English proficiency among immigrant parents are closely associated with lower wages (Capps et al. 2003).

\section{Children of Immigrants More Likely to Be in Two-Parent Families}

Children of immigrants are more likely to be in two-parent families than are children of natives, regardless of age (figure 6). Eighty-six percent of children of immigrants under 6 live in two-parent families, compared with 75 percent of young children of natives. This pattern is more striking for low-income families: low-income children of natives are evenly split between single- and two-parent households (figure 7). Low-income children of immigrants are much more likely to be living with two parents than one (79 versus 21 percent).

FIGURE 6. Share of Children in Two-Parent Families, 2002

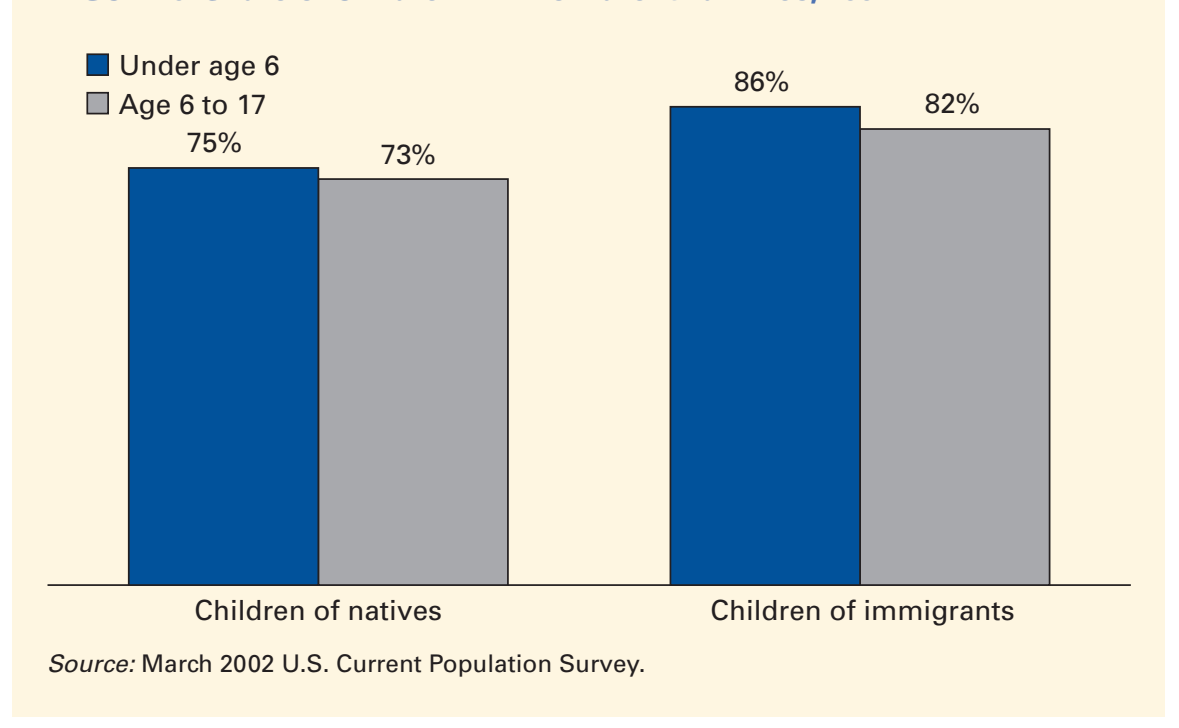


FIGURE 7. Family Structure for Low-Income Children under 6, 2002

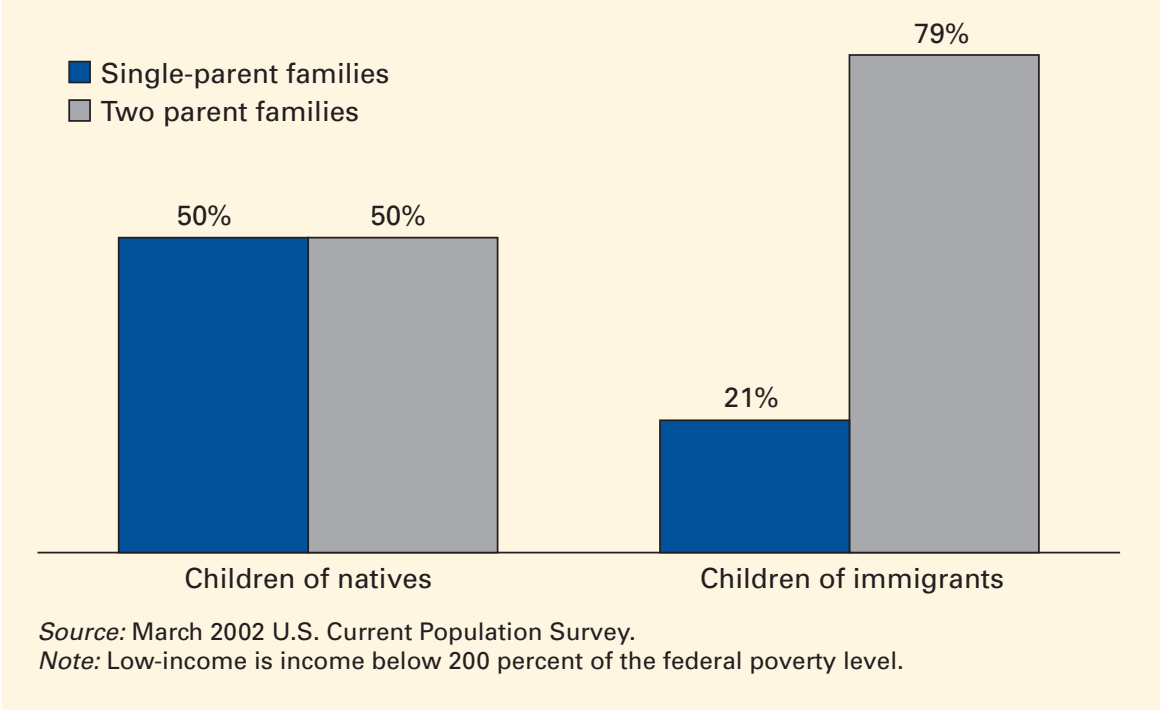

The presence of two parents can be viewed as a protective factor for young children of immigrants in terms of social development and long-term adaptation. Living in a single-parent family has been linked to poor educational performance and behavioral and psychological problems (Vandivere, Moore, and Brown 2000). Yet the presence of a second parent in the home for young children of immigrants does not necessarily translate into lower poverty rates for these children, because the second parent is less likely to work.

\section{Immigrant Families Less Likely to Have Two Working Parents}

Despite the fact that children of immigrants are more likely to live in two-parent families, they are less likely to live in families with two working parents. ${ }^{7}$ Forty-three percent of young children of immigrants live with two working parents, compared with 50 percent of young children of natives (figure 8).

These results owe primarily to relatively low labor force participation among immigrant women. Immigrant women are less likely to work than natives, in part because they are more likely to be of child-bearing age and have more children than native women (Capps et al. 2002). Shares with a second working parent are higher for older children in both immigrant and native families, but the gap between immigrant and native families persists.

These findings have several implications. On one hand, since a lower share of children in immigrant families have two working parents, their family incomes are lower than natives' children. On the other, a second parent in the home providing child care may promote healthy child development and well-being in immigrant families.

\section{High Poverty among Children of Immigrants and Children of Natives in Single-Parent Families}

Children in single-parent native and immigrant families are much more likely to live in poverty and have low incomes than their counterparts in two-parent families (figure 9). Almost two-thirds 
FIGURE 8. Share of Children with Two Working Parents, 2002

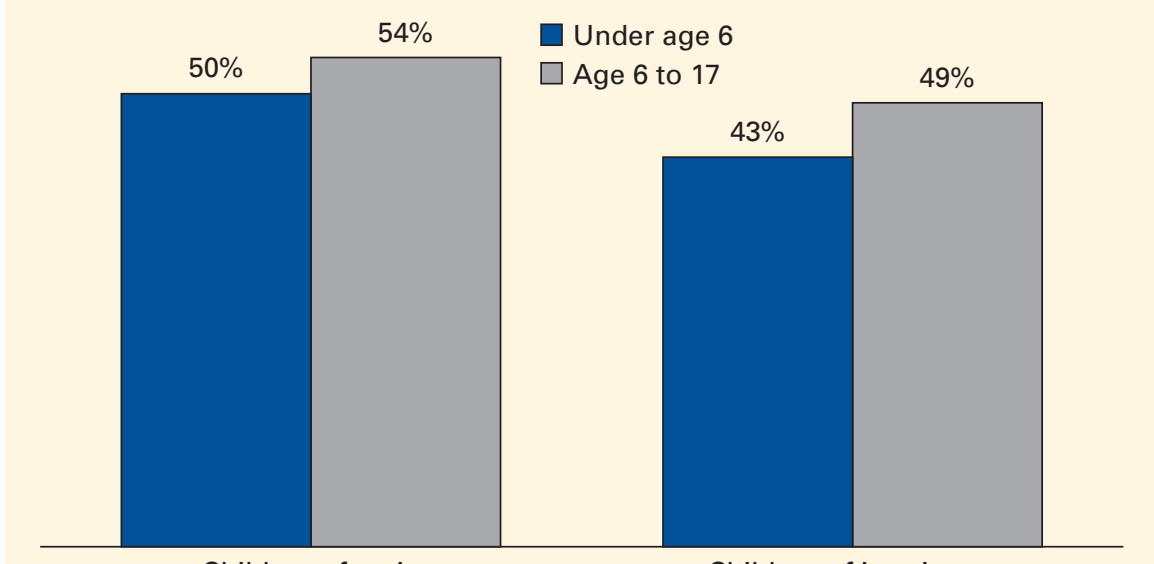

Children of natives

Children of immigrants

Source: March 2002 U.S. Current Population Survey.

FIGURE 9. Low-Income and Poverty Rates for Young Children by Family Structure, 2002

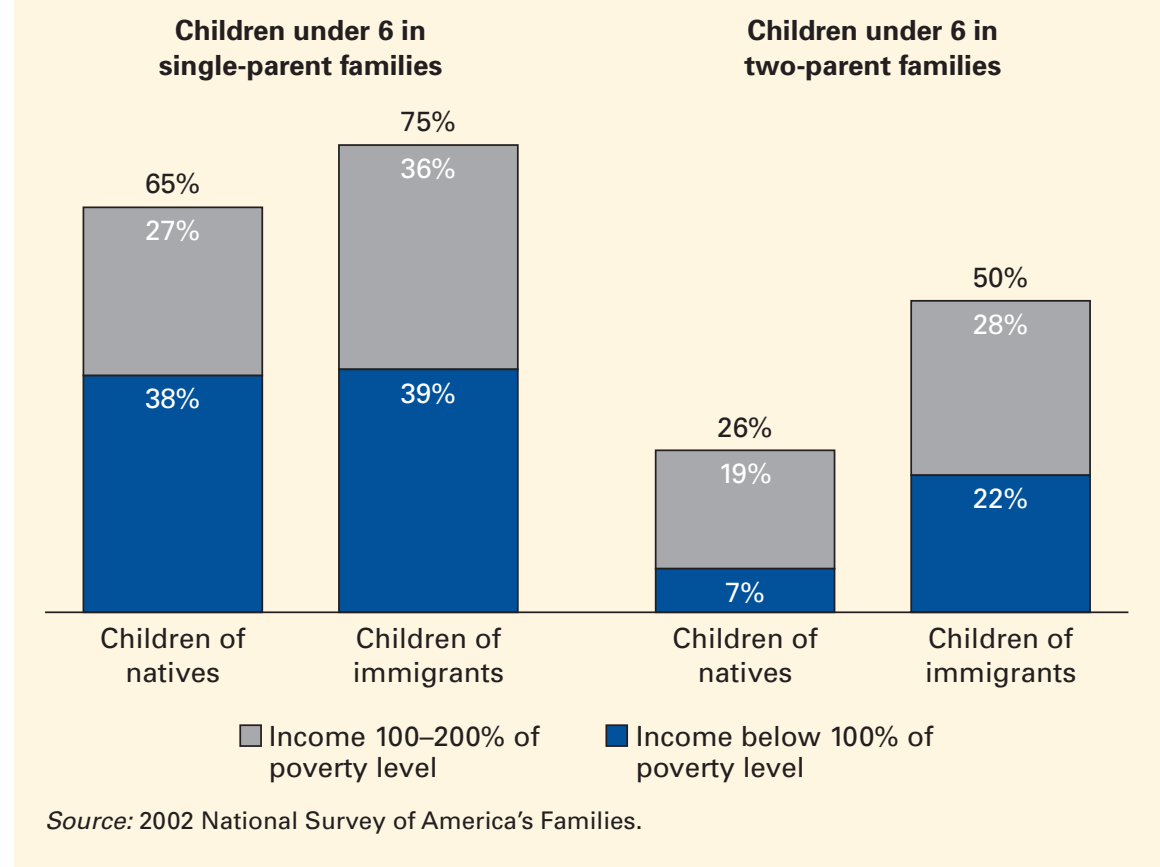

(65 percent) of young children of natives in single-parent families have low incomes. Three-quarters of young children of immigrants in single-parent families are low-income. The poverty rate for children in single-parent families is the same-almost 40 percent-regardless of the nativity of their parents. Because a relatively small share of children of immigrants lives in single-parent families 
(14 percent versus 25 percent for children of natives), the lack of a second parent does not adequately explain their relatively high overall poverty rate.

\section{Children of Immigrants in Two-Parent Families Much More Likely than Children of Natives to Be Poor}

Young children of immigrants with two parents are three times as likely as natives' children to have family incomes below the poverty level (22 versus 7 percent) and about twice as likely to be lowincome (50 versus 26 percent, as shown in figure 9$)$.

The presence of a second parent in the home does reduce poverty for young children in both native and immigrant families. However, the presence of a second parent has a greater effect on incomes in native families, as a larger share of children in two-parent immigrant families are poor. Part of the explanation for higher poverty in two-parent immigrant families is lower wages and earnings, but part is also the higher share of immigrant families where only one parent works.

\section{Much Lower Poverty in Families with Two Working Parents, but the Gap between Immigrants and Natives Persists}

The share of families that are low-income falls sharply when both parents work (figure 10). Nonetheless, even in families where both parents work, almost a quarter of children of immigrants are low-income, a rate more than twice that for children of natives.

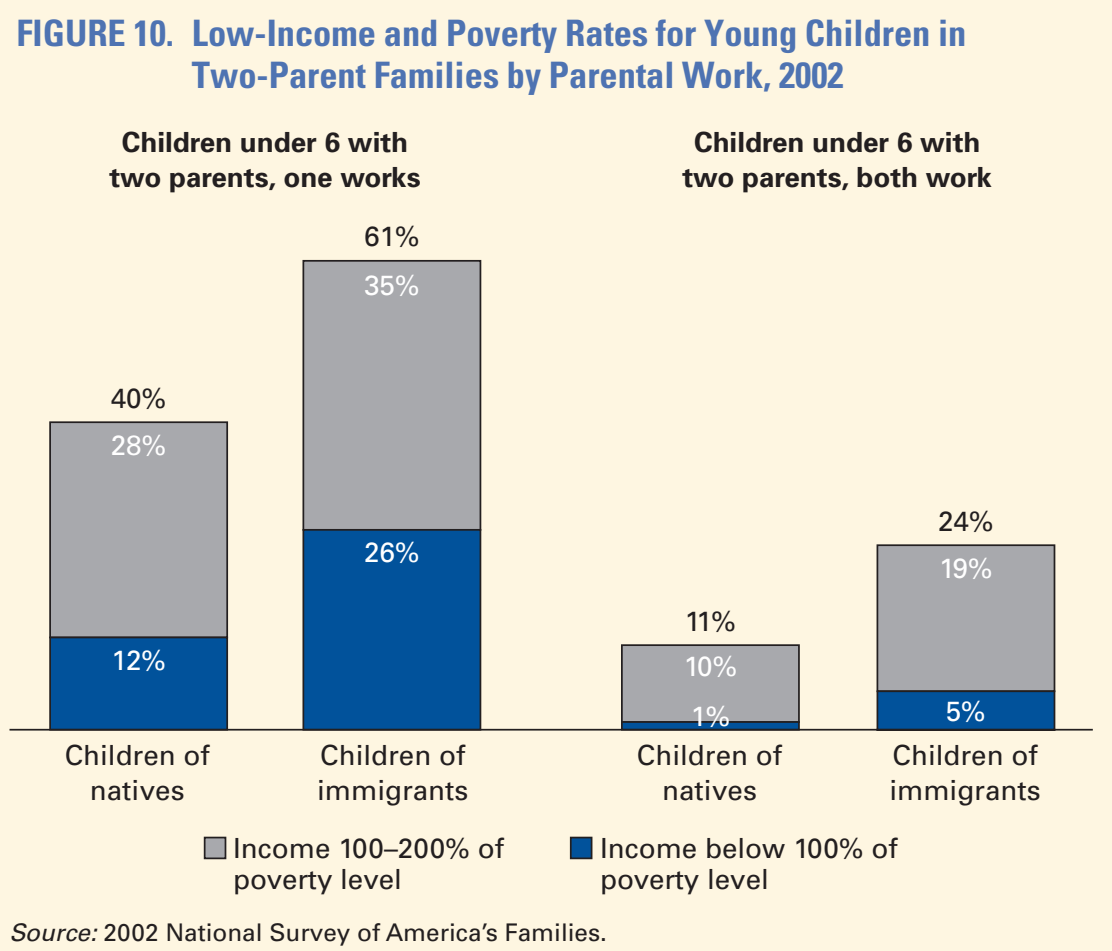




\section{Wages Lower for Immigrant Parents}

The most important factor explaining higher poverty among children of immigrants is the lower wages their parents earn. The median hourly wage for native parents of young children was about $\$ 17.00$ in $2002 .{ }^{8}$ For immigrant parents of young children, the median hourly wage was only about $\$ 13.00$ for the higher-earning parent (figure 11).

FIGURE 11. Median Hourly Wage Earned by Higher-Earning Parent, 2001

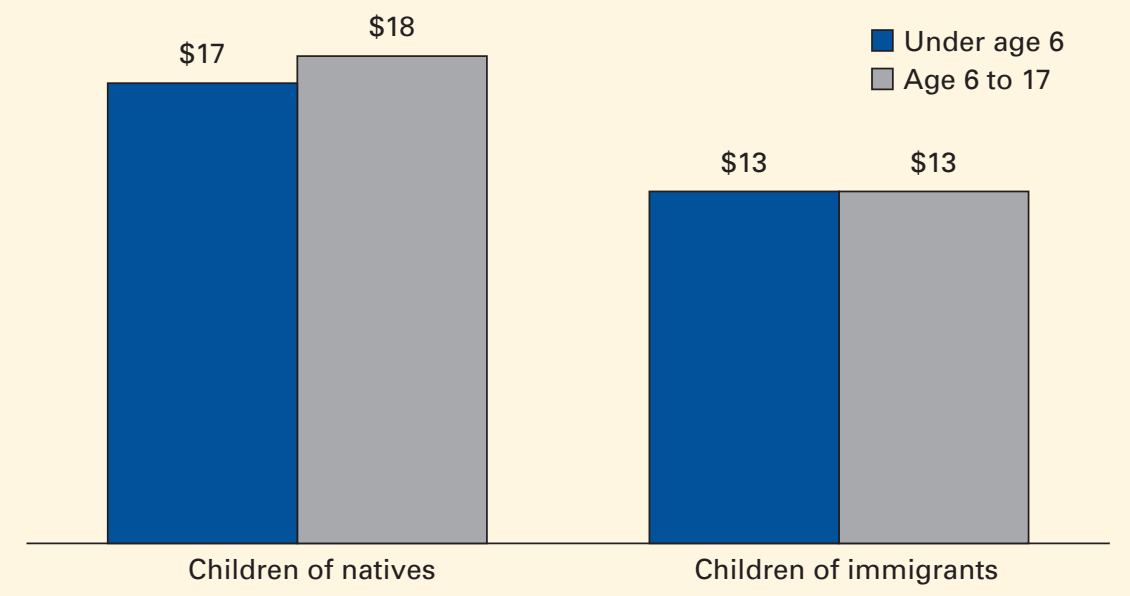

Source: March 2002 U.S. Current Population Survey.

Note: Median hourly wage is total earnings divided by weeks worked and average hours worked a week for the year before the survey, excluding zero earners.

\section{Policy Implications}

Taken together, our findings on family structure and poverty suggest that work and marriage are not antidotes to poverty in immigrant families with young children. The findings also suggest that marriage promotion policies may have less impact on low-income immigrant than native families, since a larger share of immigrant families are married, two-parent families (ReardonAnderson, Capps, and Fix 2002). Because wages are lower for immigrant parents, minimum wage rules and other efforts to increase earnings in lower-wage jobs should boost family incomes and reduce child poverty. Lower educational attainment and limited English proficiency are strongly linked to lower wages (Capps et al. 2002), so many immigrant parents may need additional education and training services. 


\section{RISK FACTORS FOR POOR SCHOOL PERFORMANCE AMONG YOUNG CHILDREN OF IMMIGRANTS}

Young children of immigrants have many risk factors associated with poor school performance. Research shows that low-income children and children who have parents with low educations and limited English skills often perform poorly in school and, later, in the labor force (NRC and IOM 2000). At the same time, children of immigrants score lower on measures of parent-child interaction at young ages than do children of natives.

\section{Three in Ten Children of Immigrants Have Parents without a High School Degree}

On average, immigrant parents have significantly less formal education than do native-born parents, and many are not proficient in English. Thirteen percent of children of immigrants under 6 have parents with less than a ninth grade education, and another 16 percent have parents who finished ninth grade but lack a high school diploma (figure 12). ${ }^{9}$ By contrast, only 8 percent of children of natives have parents with less than a high school education.

FIGURE 12. Distribution of Children under 6 by Parents' Education Levels, 2002

Children of immigrants

$\square$ Children of natives

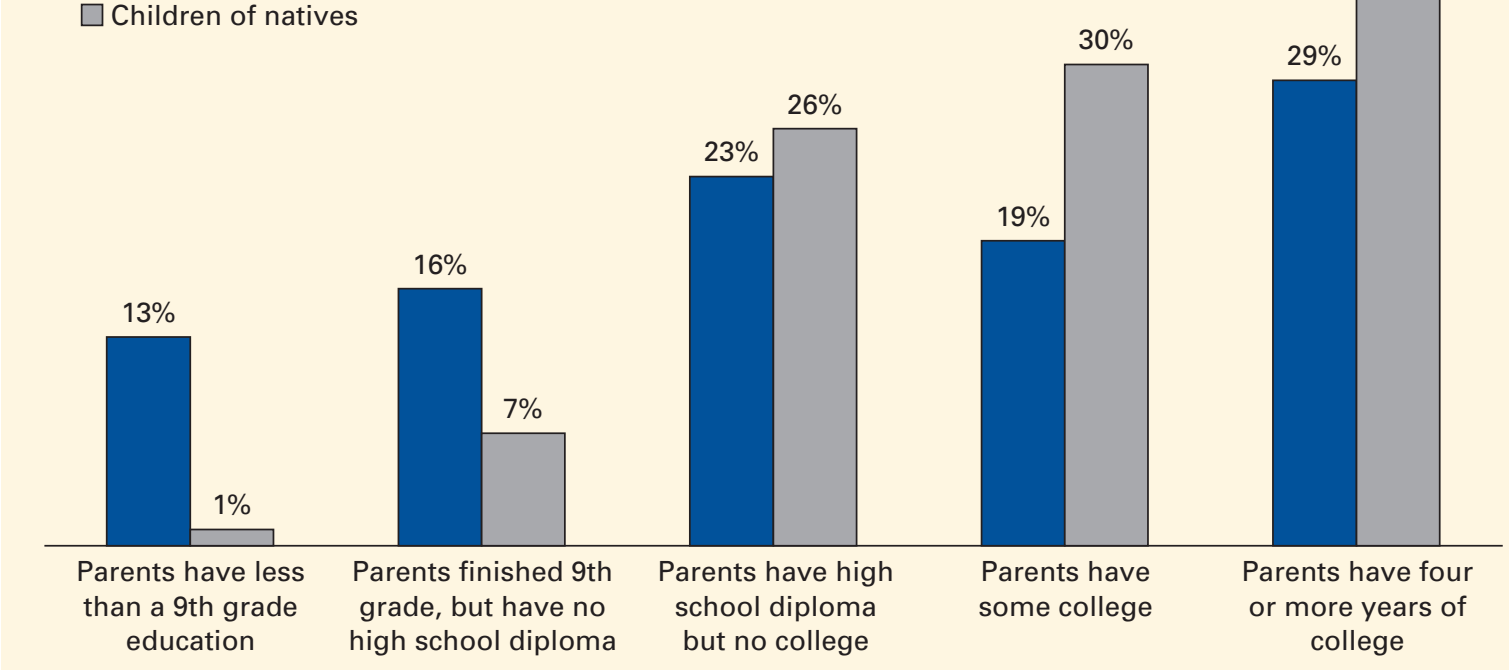

Source: March 2002 U.S. Current Population Survey.

Note: Based on educational attainment of better-educated parent. 
Even at the higher end of the educational spectrum, native parents are better educated than immigrant parents. There is an 11 percentage point gap between young children of immigrants and those of natives who have a parent with at least some college education. The gap shrinks somewhat to 7 percentage points for children with a parent completing four or more years of college.

\section{Six in Ten Have Limited English Proficient Parents}

Over a quarter (27 percent) of all children under 6 in the United States and the vast majority (87 percent) of young children in immigrant families have at least one parent who speaks a language other than English at home. In contrast, a small but nontrivial share (11 percent) of young children of natives has at least one parent who speaks a language other than English at home.

Fourteen percent of all children under 6 in the United States have at least one parent who is limited English proficient (LEP), and 58 percent of all young children of immigrants have at least one LEP parent. ${ }^{10}$ Over half of native-born and two-thirds of foreign-born children of immigrants have at least one LEP parent (figure 13). By contrast, only a very small fraction (2 percent) of children of natives live in families where either parent is LEP. At the same time, a substantial share (29 percent) of young children of immigrants has parents who are bilingual—-they speak a language other than English at home but also speak English very well.

\section{One-Third Live in Linguistically Isolated Households}

About one-third (32 percent) of all children of immigrants under age 6 live in "linguistically isolated" households, where all persons age 14 and over are LEP. Foreign-born children are more likely to live in linguistically isolated households than are U.S.-born children of immigrants (44 versus 31 percent, as shown in figure 14). Only 1 percent of young children in native families live in such households.

Older children of immigrants are somewhat less likely to live in linguistically isolated households than younger children (23 versus 32 percent). Older children are more likely to have parents who have been in the country longer, and therefore have had more time to acculturate and learn English.

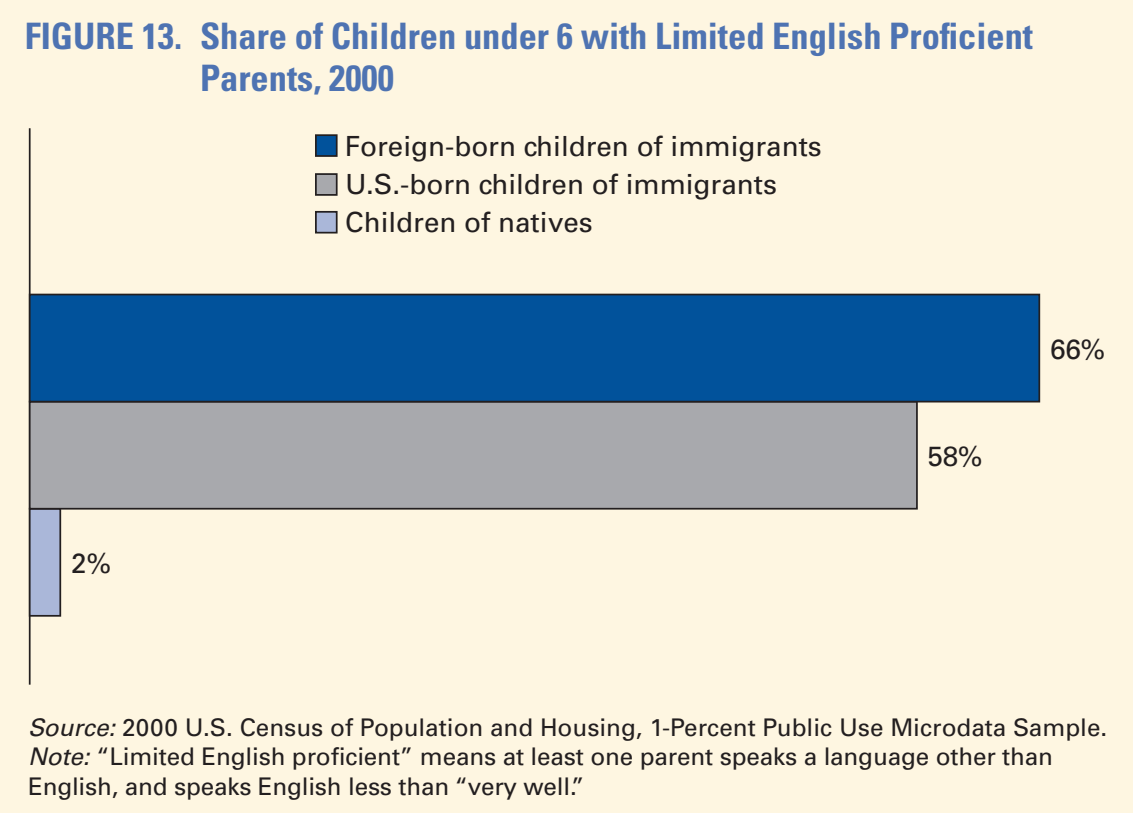


FIGURE 14. Share of Children under 6 in Linguistically Isolated Households, 2000

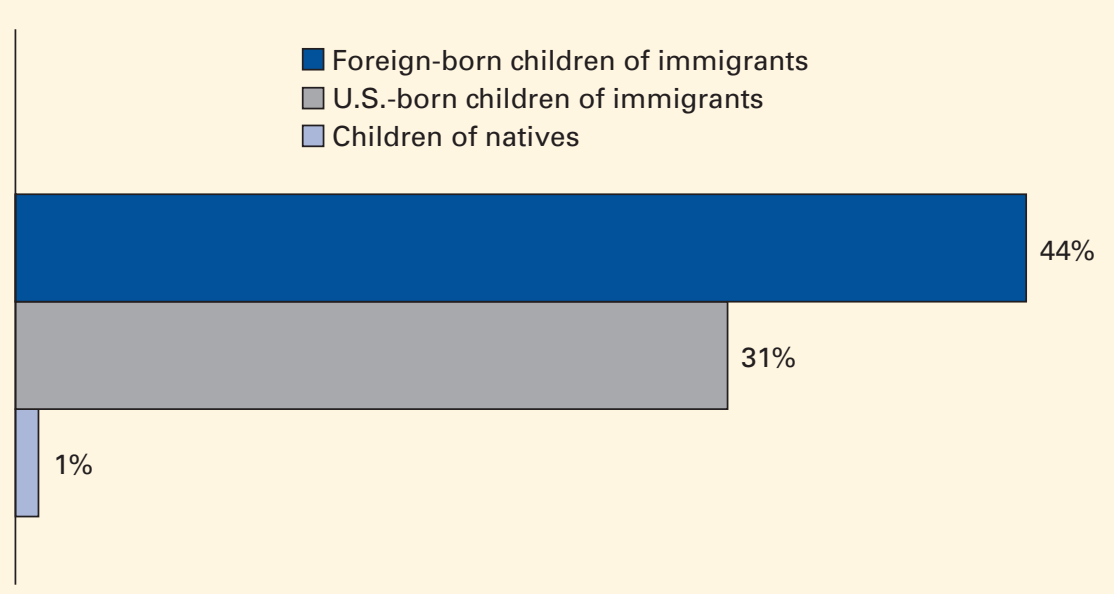

Source: 2000 U.S. Census of Population and Housing, 1-Percent Public Use Microdata Sample. Note: Linguistically isolated households are those in which no household member over 14 years old speaks English "very well."

Also, older children are themselves more likely to speak English, because they have been in the country and in school longer.

\section{Parent-Child Interaction Lower in Immigrant Families}

Young children of immigrants do not fare as well as children of natives on measures of parent-child interaction. About three-quarters of young children in immigrant families are read to by their parents at least three times a week, compared with nearly 90 percent of children in native families (figure 15).

FIGURE 15. Interaction with Parents for Children under 6, 2002

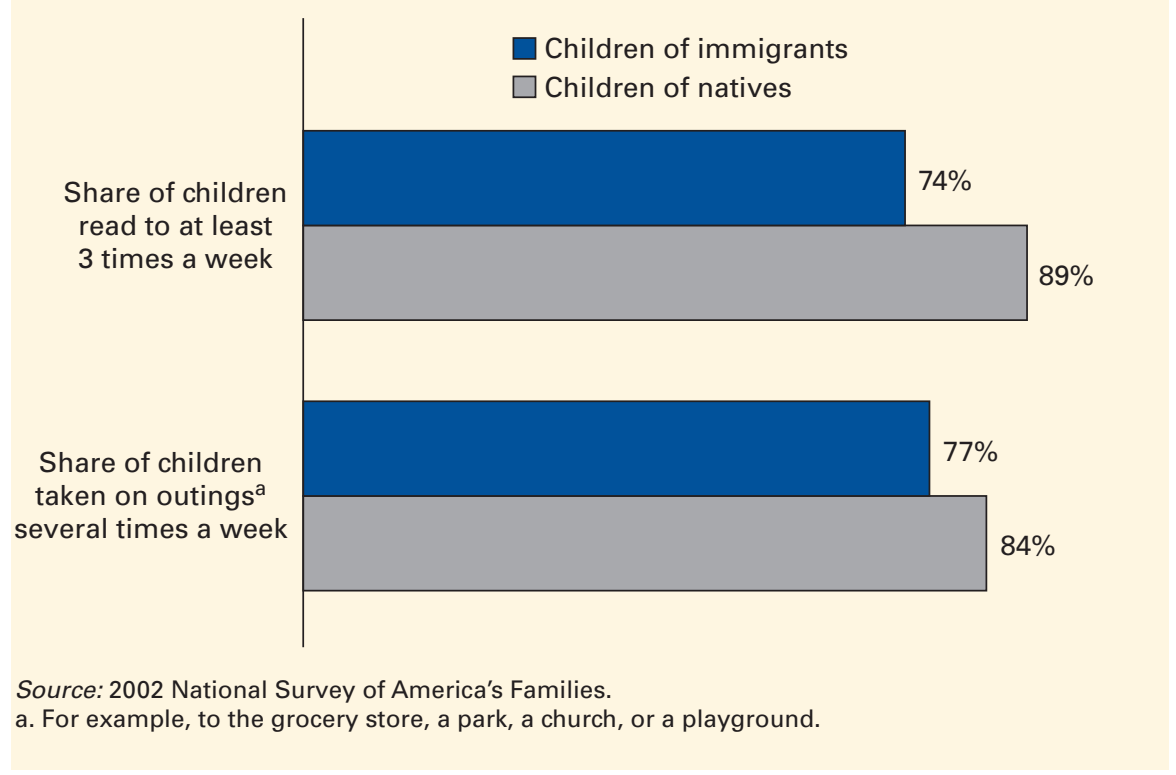


Children of immigrants are also less likely to be taken on outings — such as to the grocery store, a park, a church, or a playground - than children of natives (77 versus 84 percent). These gaps may be associated with relatively high poverty and low educational attainment in immigrant families.

\section{Policy Implications}

Our previous research suggests that immigrants who lack English proficiency and have lower educational attainment earn lower wages (Capps et al. 2003) and are less likely to naturalize. As we have written elsewhere (Fix, Passel, and Sucher 2003), citizenship remains an important prerequisite for obtaining federal public benefits such as TANF or Medicaid for legal immigrants admitted after welfare reform's enactment in 1996. Lack of English proficiency is also strongly associated with poverty, food insecurity, and other forms of economic hardship in immigrant families (Capps et al. 2002). Further, limited English skills may lead to difficulty navigating schools, health providers, and other public and private community institutions (Holcomb et al. 2003).

Lower parental education and English proficiency can also impede children of immigrants' school readiness and learning since parents' human capital has been strongly linked to behavior, learning, and achievement (NRC and IOM 2000). Parents with less formal education appear less likely to enroll their children in center-based care or preschool (as we explore later). They may also have fewer resources at home (such as books or computers) to prepare their children for school. 


\section{HARDSHIP AND BENEFIT USE AMONG YOUNG CHILDREN OF IMMIGRANTS}

\section{High Levels of Economic Hardship}

Young children in immigrant families generally have higher poverty and hardship rates, but participate less in public benefit and work support programs than native families. Young children of immigrants face greater food- and housing-related hardship. Children of immigrants are 13 percentage points more likely than children of natives to live in families with one or more food-related problems and 8 percentage points more likely to live in families with two or more such problems (figure 16). ${ }^{11}$

Differences in housing hardship measures are even more striking. Young children of immigrants are four times more likely than young children of natives to live in crowded housing (defined as more than two persons per bedroom), and they are twice as likely to live in families spending over half their monthly income on rent or mortgage costs.

FIGURE 16. Food and Housing Hardship Rates for Children under 6, 2002

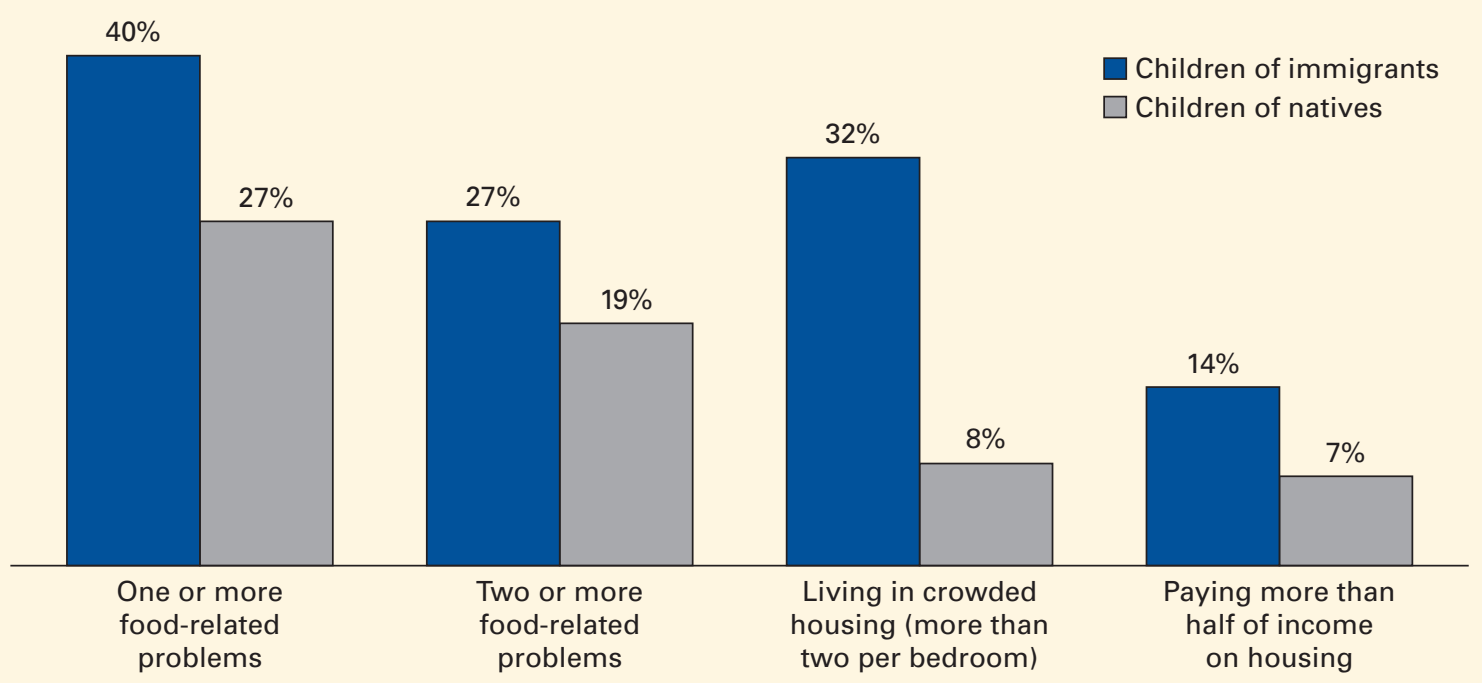

Source: 2002 National Survey of America's Families. 


\section{Economic Hardship Higher in Low-Income Immigrant Families, but Gap with Natives Narrows}

When we focus exclusively on low-income families, economic hardship rates rise, and gaps between immigrant and native families narrow for food hardship measures (figure 17). Over half (56 percent) of young, low-income children of immigrants live in families with one or more food-related problems; 39 percent live in families with two or more such problems.

The difference between children of immigrants and children of natives also narrows in the share of children in families paying more than half their income on housing: 25 versus 19 percent. But when it comes to overcrowding, the gap increases: almost half ( 46 percent) of low-income children of immigrants under age 6 live in crowded housing, a rate almost three times that for low-income children of natives (17 percent).

Patterns of food hardship seem more responsive to income levels than the housing measures. While the gap in food hardship between children of immigrants and those of natives is almost erased when only low-income families are considered, a significant gap in the share of families paying more than half their incomes on housing costs remains, and the gap in crowded housing actually increases. Part of the explanation for why housing measures are less sensitive to income may lie in the larger share of low-income immigrant families who live in expensive urban areas-New York, Los Angeles, and Chicago, for instance. Low-income native families are more likely to live in rural areas, where housing costs are lower.

\section{Children of Immigrants Less Likely to Receive Public Benefits}

Despite higher poverty and greater hardship, young children of immigrants are less likely to receive public benefits (figure 18). Young low-income children of natives are about twice as likely as their counterparts in immigrant families to have received TANF (17 versus 7 percent) or food stamps

FIGURE 17. Food and Housing Hardship Rates for Low-Income Children under 6, 2002

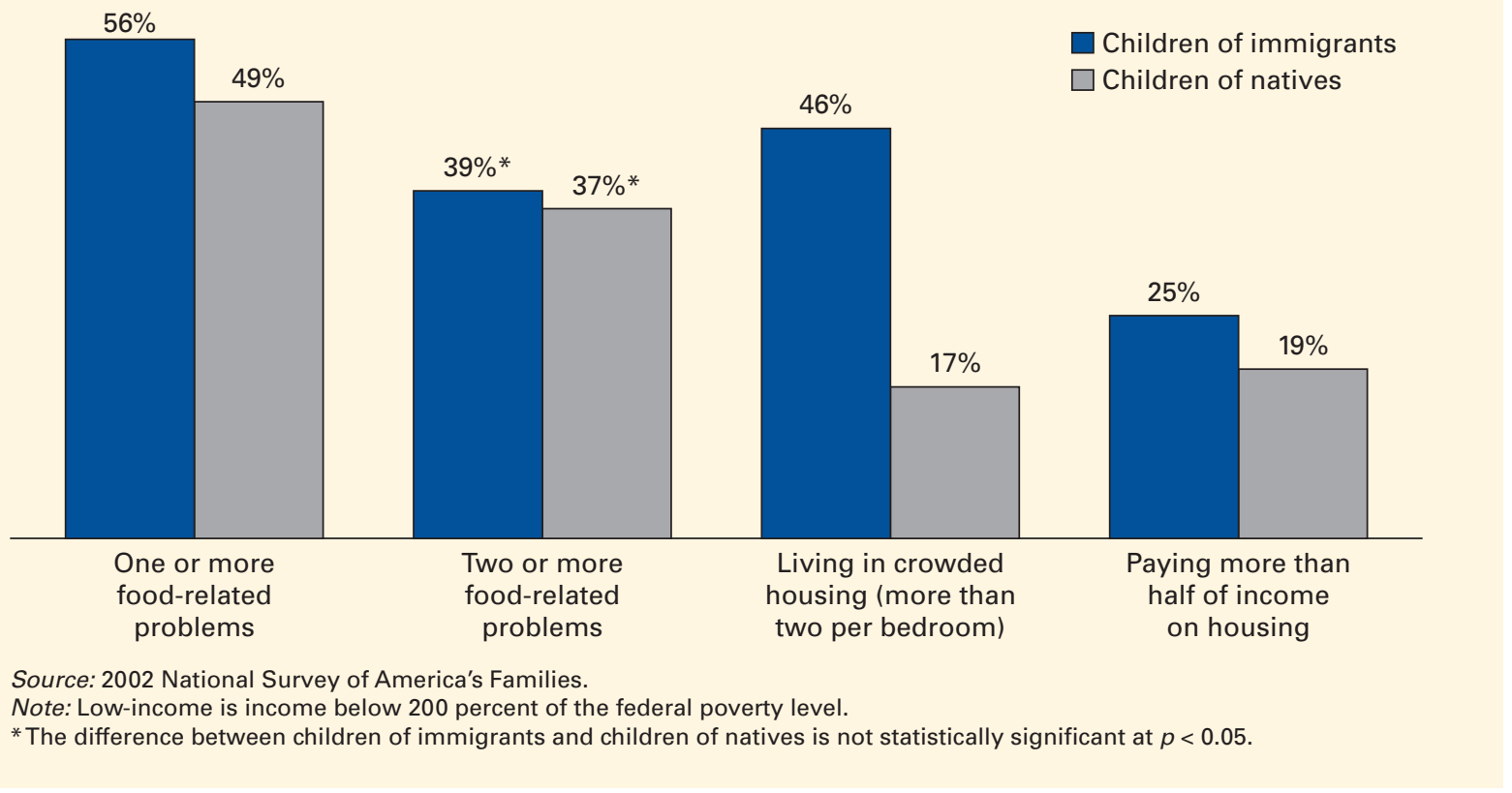


FIGURE 18. Share of Low-Income Children under 6 Receiving Public Benefits, 2002

Children of immigrants

$\square$ Children of natives

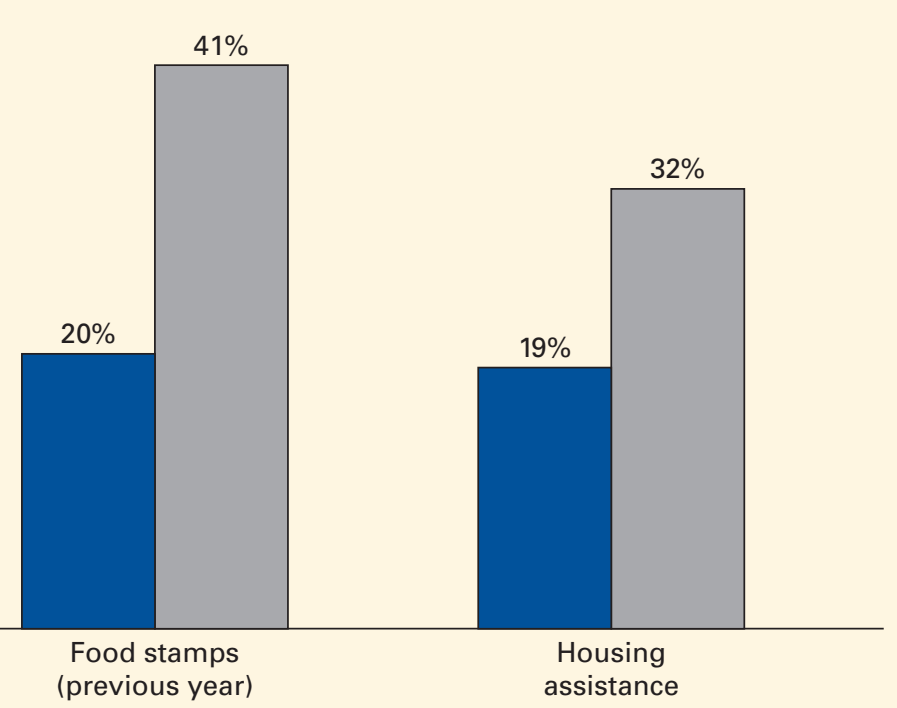

Source: 2002 National Survey of America's Families.

Note: Low-income is income below 200 percent of the federal poverty level.

(41 versus 20 percent) in the previous year. And low-income children of natives are more likely than their peers in immigrant families to receive housing assistance. ${ }^{12}$

The relatively high rate of TANF participation among native families may be explained by the higher share of single-parent families in this group. Another explanation is that many immigrant parents are ineligible for both TANF and food stamps because they are either undocumented or recent legal immigrants. ${ }^{13}$ Nonetheless, the vast majority of young children of immigrants in low-income families should be eligible because they are U.S.-born citizens. Beyond income support, limited TANF use among low-income children of immigrants carries implications for child care arrangements, as TANF is an important gateway to federal and state child care subsidies. 


\section{Policy Implications}

Despite higher levels of need for income support or food and housing assistance, low-income immigrant families are less likely to participate in public benefit programs such as TANF, food stamps, and housing assistance. Part of the explanation for this disparity lies in the eligibility rules for these programs, which generally exclude undocumented immigrants and legal immigrants who have not yet become citizens or met other eligibility criteria set out in the 1996 Personal Responsibility and Work Opportunity Reconciliation Act (PRWORA). Despite subsequent restorations in Supplemental Security Income and the Food Stamp Program, many legal immigrants remain ineligible for federally funded public benefits if they have not been in the country at least five years, naturalized, or entered as refugees. While some states have restored legal immigrants' eligibility using state funding, many legal immigrants who entered the country following PRWORA's enactment remain ineligible in most states (Zimmermann and Tumlin 1999). As a result of these eligibility restrictions, the participation of legal immigrants in public benefit programs has fallen considerably since PRWORA's passage (Fix and Passel 2002).

These noncitizen eligibility restrictions seldom apply directly to young children of immigrants, the vast majority of whom (93 percent) are U.S. citizens. Yet the participation of immigrant families with noncitizen parents and citizen children also fell quickly following PRWORA, particularly in the Food Stamp Program (Cunnyngham 2003). There are several reasons immigrants may not participate in assistance programs, even when they or their children are eligible. Many immigrants are confused about the eligibility rules, and others are concerned about the effects that using benefits may have on their ability to become U.S. citizens or to sponsor their relatives' immigration to the United States (Capps, Hagan, and Rodriguez 2004). Families with undocumented members fear being reported to the immigration authorities. Although some of these concerns are unfounded, they have nonetheless depressed immigrant families' participation in public benefit programs. Moreover, some families are intimidated by interaction with public agencies because of language and cultural barriers (Holcomb et al. 2003; Zimmermann and Fix 1998). 


\section{HEALTH STATUS AND INSURANCE COVERAGE}

\section{Children of Immigrants Twice as Likely to Be in Fair or Poor Health and Lack a Usual Source of Care}

Children in immigrant families_-both young and older-are considerably more likely to be uninsured, to be reported in fair or poor health, and to lack a usual place where they can get preventive health care. Seven percent of young children of immigrants are reported in fair or poor health by their parents, more than twice the rate for children of natives (3 percent, as shown in figure 19). ${ }^{14}$ More than twice as many young children of immigrants as natives lack a usual source of health care ( 8 versus 3 percent). ${ }^{15}$

When only low-income families are considered, the share of young children of immigrants in fair or poor health rises slightly from 7 to 9 percent. The share without a usual source of health care increases from 8 to 12 percent, and differences between children of immigrants and those of natives widen. These health measures appear to be somewhat correlated with income, but other factors, such as lower insurance coverage and access to health care, may also affect the health of children of immigrants.

FIGURE 19. Share of Children in Fair or Poor Health or without a Usual Source of Health Care, 2002

Children under age 6

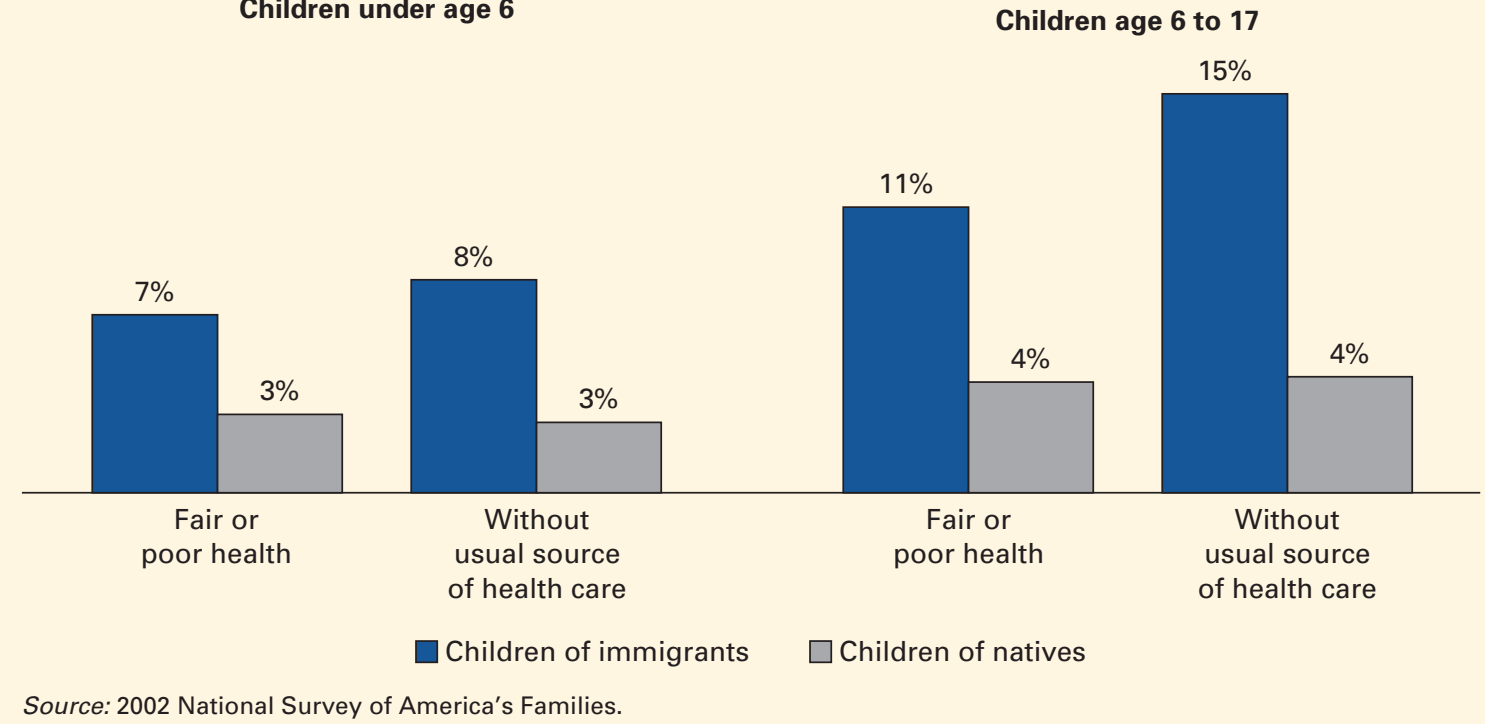




\section{Older Children of Immigrants Fare Worse on Health Status and Access Measures}

Older children (age 6 to 17), however, fare substantially worse on both health status and access measures (figure 19). Eleven percent of older children of immigrants are reported in fair and poor healtha rate almost three times that for older children of natives (4 percent) and substantially higher than that for younger children of immigrants (7 percent). Fifteen percent of older children of immigrants lack a usual source of health care, nearly four times the rate for older children of natives ( 4 percent) and almost twice the rate for younger children of immigrants (8 percent).

Low-income older children fare worse: 16 percent are reported in fair or poor health, and 21 percent lack a usual source of health care. Low-income older children may be the most at risk for poorer health behaviors and the most disconnected from the health care system; they are also the most likely to be noncitizens who are ineligible for publicly funded health insurance.

\section{Twice as Likely to Be Uninsured, but Rate Falls from 1999 to 2002}

In 2002, the share of young children of immigrants without health insurance was more than twice as high as the rate for young children of natives (14 versus 6 percent), despite improvements in health care coverage between 1999 and 2002 (figure 20). The share of children of immigrants under age 6 without health insurance fell from 18 to 14 percent between 1999 and 2002, a substantial drop in only three years. ${ }^{16}$

We see similar trends in insurance coverage when we compare younger to older children of immigrants, and when we focus on low-income children. Uninsurance declined for older children age 6 to 17, but 20 percent of older children were uninsured in 2002, more than twice the rate for older children of natives (8 percent). The share of young low-income children of immigrants without health insurance also fell, ${ }^{17}$ although in 2002 low-income children of immigrants under 6 re-

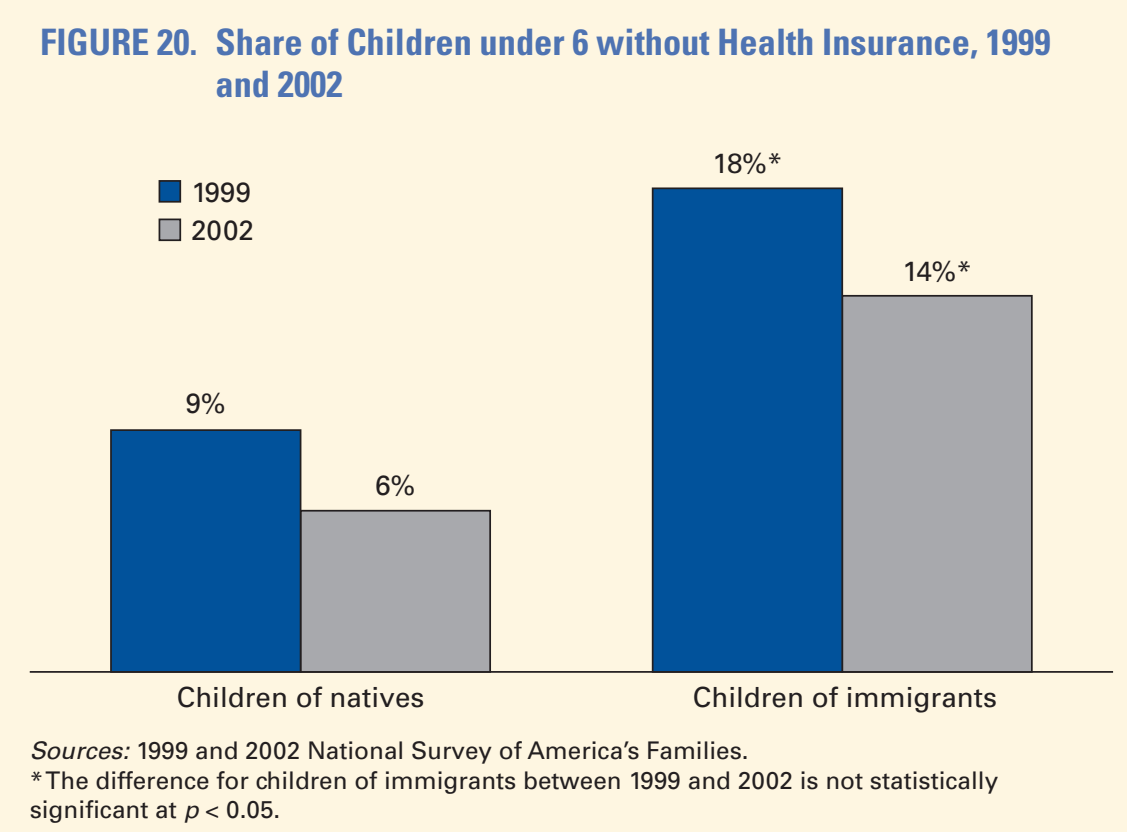


mained twice as likely to be uninsured as low-income children of natives (22 versus 11 percent, as shown in figure 21).

\section{Coverage of Children of Immigrants through Medicaid and SCHIP Improving}

A correlate of declining uninsurance is rising public coverage through Medicaid, SCHIP, and similar programs funded by state and local governments. The period from 1999 to 2002 saw substantial expansions in public coverage of young low-income children in both immigrant and native families. In fact, both groups show significant rates of change in coverage over time.

By 2002, over half of young low-income children in both immigrant and native families were covered by Medicaid, SCHIP, or similar state-funded programs, and rates had risen significantly in just three years (figure 22). ${ }^{18}$ Research by the Urban Institute in six states in 2001 found that most were making substantial efforts to simplify Medicaid and SCHIP eligibility and provide families opportunities to enroll outside of traditional welfare and social service offices. Some of these states had also started major outreach programs (Holcomb et al. 2003). Enrollment figures from four major destination states (California, New York, Texas, and Florida), as well as studies on take-up rates for these programs, suggest that simplification and outreach have increased public coverage over the past few years (Kenney, Haley, and Tebay 2003; Dubay, Hill, and Kenney 2002). ${ }^{19}$ It remains to be seen, however, whether these expansions in public coverage for children can be sustained given changes in national and state fiscal conditions. ${ }^{20}$

\section{Employer Coverage for Children of Immigrants Falling}

At the same time that public health insurance coverage for children under age 6 has increased, coverage through their parents' employers has been falling. Between 1999 and 2002, employer cov-

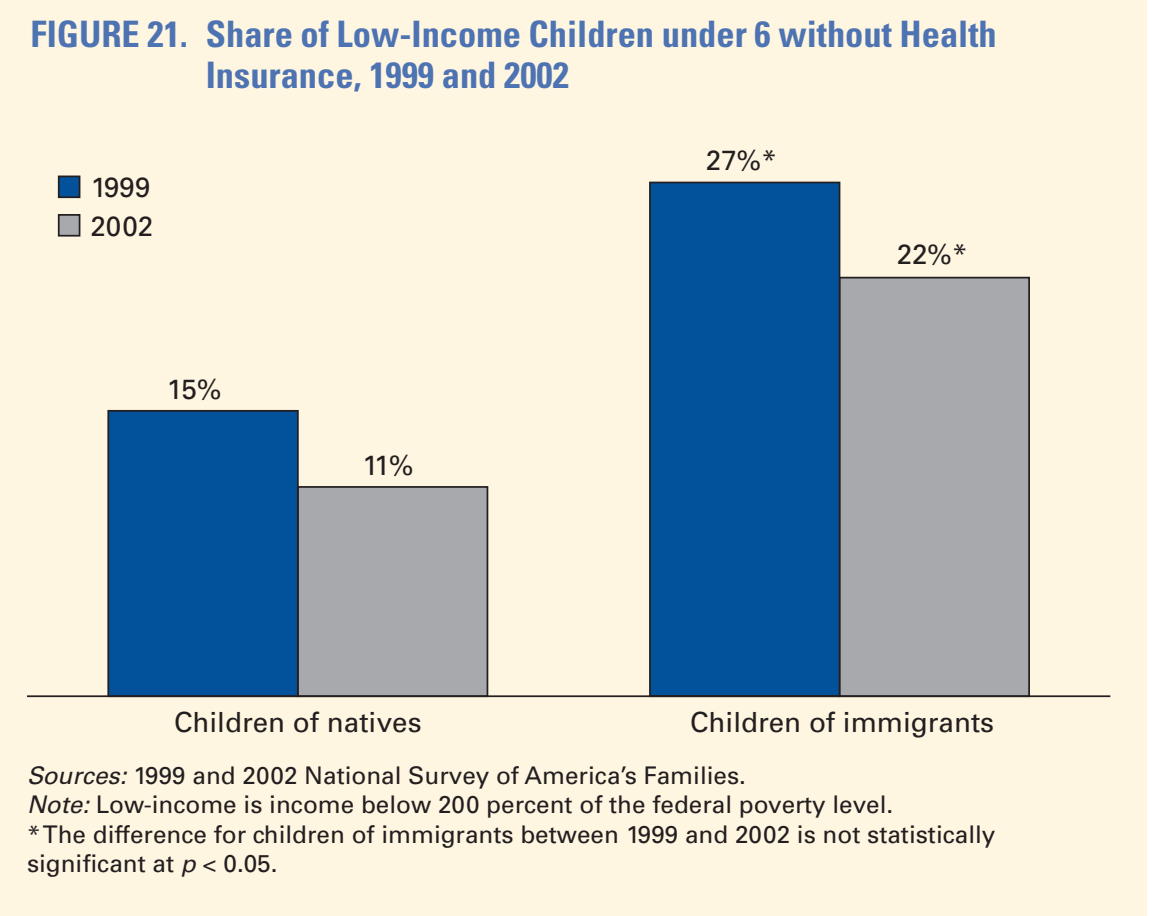




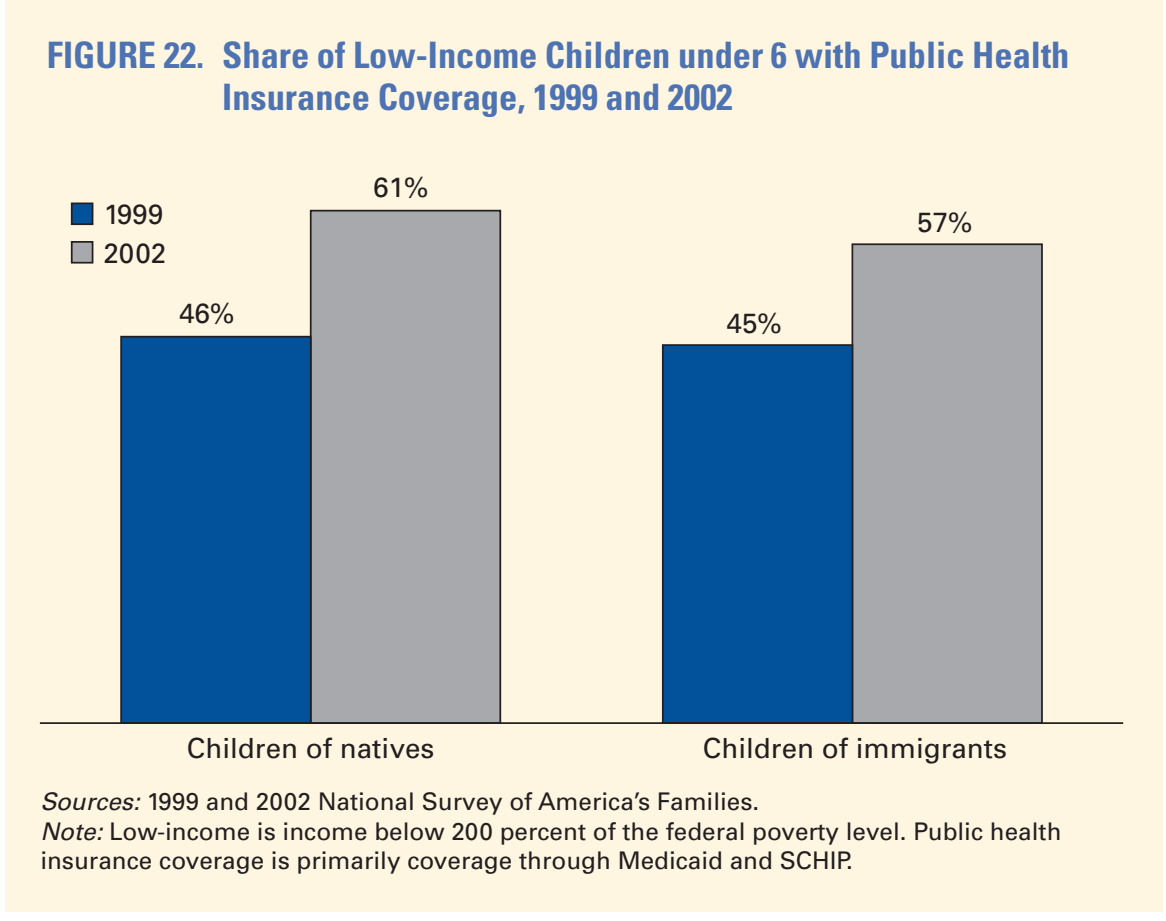

erage fell by 4 percentage points among young low-income children of immigrants ${ }^{21}$ and by 5 percentage points for young low-income children of natives. In 2002, low-income children of natives were considerably more likely to have employer-based coverage than low-income children of immigrants (31 versus 22 percent).

\section{Policy Implications}

These findings suggest that public coverage is more critical for young children in immigrant families than those in native families, because a lower share receives coverage through their parents' employers. These findings also highlight the potential value of Medicaid and SCHIP outreach targeted toward immigrant families, as well as efforts to reduce access barriers (e.g., translation and interpretation). Ninety-three percent of young children of immigrants are U.S.-born citizens and therefore eligible for both programs if they meet other eligibility criteria. Roughly half of the remaining 7 percent could benefit from efforts to extend public coverage to recent legal immigrants, with the balance potentially benefiting from proposals that might legalize undocumented children. ${ }^{22}$ Higher uninsurance rates among older children of immigrants suggest that some targeting of outreach might be directed to this population. 


\section{CHILD CARE ARRANGEMENTS}

\section{Young Children of Immigrants Less Likely to Be in Child Care}

Children of immigrants under age $6^{23}$ are less likely to be in regularly scheduled child care than children of natives ${ }^{24}$ but the reasons for this gap are not well understood. Differences in family structure and the cultural values of immigrant parents may affect the child care arrangements that parents prefer (Takanishi 2004). Immigrants' lower use of child care may be partially explained by the lower share of second parents who work. Immigrant parents may also face barriers to child care access, such as cost, eligibility for subsidies, language barriers, legal status, and the availability of nearby care.

Sixty-six percent of natives' children under age 6 are in one of four principal forms of nonparental child care, versus 47 percent of children of immigrants (table 1). When we look in more detail at child care arrangements, 26 percent of children of natives under age 6 are in center-based care (which includes day care centers, Head Start, nursery school, preschool and pre-kindergarten), ${ }^{25}$ compared with 17 percent of children of immigrants. ${ }^{26}$ Another 26 percent of children of natives are cared for primarily by other relatives, compared with only about 20 percent of children in immigrant families. Comparatively few children are cared for in a nonrelative provider's home: 9 percent for children of natives versus 7 percent for those of immigrants. Nannies and babysitters (i.e., nonrelatives in the child's home) care for 5 percent of children of natives and 3 percent of children of immigrants.

TABLE 1. Child Care Arrangements for Children under 6, 2002

\begin{tabular}{lcc} 
Child care arrangement & $\begin{array}{c}\text { Children of natives } \\
\text { (percent) }\end{array}$ & $\begin{array}{c}\text { Children of immigrants } \\
\text { (percent) }\end{array}$ \\
\hline Parental care/no regular arrangement & 34.4 & 52.8 \\
Nonparental & 65.6 & 47.2 \\
Center-based & 26.0 & 17.0 \\
Relative-provided & 25.5 & 20.4 \\
Home of a nonrelative & 9.2 & 6.9 \\
Nanny or babysitter & 4.9 & 2.9 \\
All arrangements & 100.0 & 100.0
\end{tabular}

Sources: 1999 and 2002 National Survey of America's Families.

Note: Excludes children enrolled in school. 


\section{Gap in Child Care Narrows for Children with Working Parents}

The share of children in child care rises and the gap between immigrants and natives narrows when we consider only those children with working parents (table 2). ${ }^{27}$ The share of children of natives in child care increases from 66 to 78 percent; the share of children of immigrants rises even more substantially-from 47 to 70 percent. Nonetheless, children of natives with working parents are 8 percent more likely to be in child care than comparable children of immigrants.

TABLE 2. Child Care Arrangements for Children under 6 with Working Parents, 2002

\begin{tabular}{ccc} 
Child care arrangement & $\begin{array}{c}\text { Children of natives } \\
\text { (percent) }\end{array}$ & $\begin{array}{c}\text { Children of immigrants } \\
\text { (percent) }\end{array}$ \\
\hline Parental care/no regular arrangement & 22.1 & 30.0 \\
Nonparental & 77.9 & 70.0 \\
Center-based & 30.3 & 22.6 \\
Relative-provided & 27.6 & $31.8^{*}$ \\
Home of a nonrelative & 14.2 & $11.9^{*}$ \\
Nanny or babysitter & 5.7 & $3.7^{*}$ \\
All arrangements & 100.0 & 100.0
\end{tabular}

Source: 2002 National Survey of America's Families.

Note: Each working parent works at least 20 hours a week on average.

* The difference between children of immigrants and children of natives is not statistically significant at $p<0.05$.

\section{Gap in Center-Based Care Most Pronounced}

When we look at differing arrangements for children with working parents, we only find a statistically significant gap between children of immigrants and natives in center-based care: 30 versus 23 percent.

\section{Low-Income Children of Immigrants Less Likely to Be in Center-Based Care}

We see similar patters for center-based care among low-income families. When compared with children overall, children in low-income families are relatively less likely to be in center-based care-an important finding considering that young children of immigrants are much more likely to be lowincome than young children of natives. Among low-income children, those with immigrant parents are significantly less likely to be in center-based care than those in native families ( 11 versus 18 percent, as shown in figure 23). Low-income children arguably need center-based care to help them prepare for school and overcome difficulties associated with childhood poverty and hardship. Moreover, only 15 percent of low-income children of immigrants with working parents are in center-based care, compared with 23 percent of comparable children of natives. 


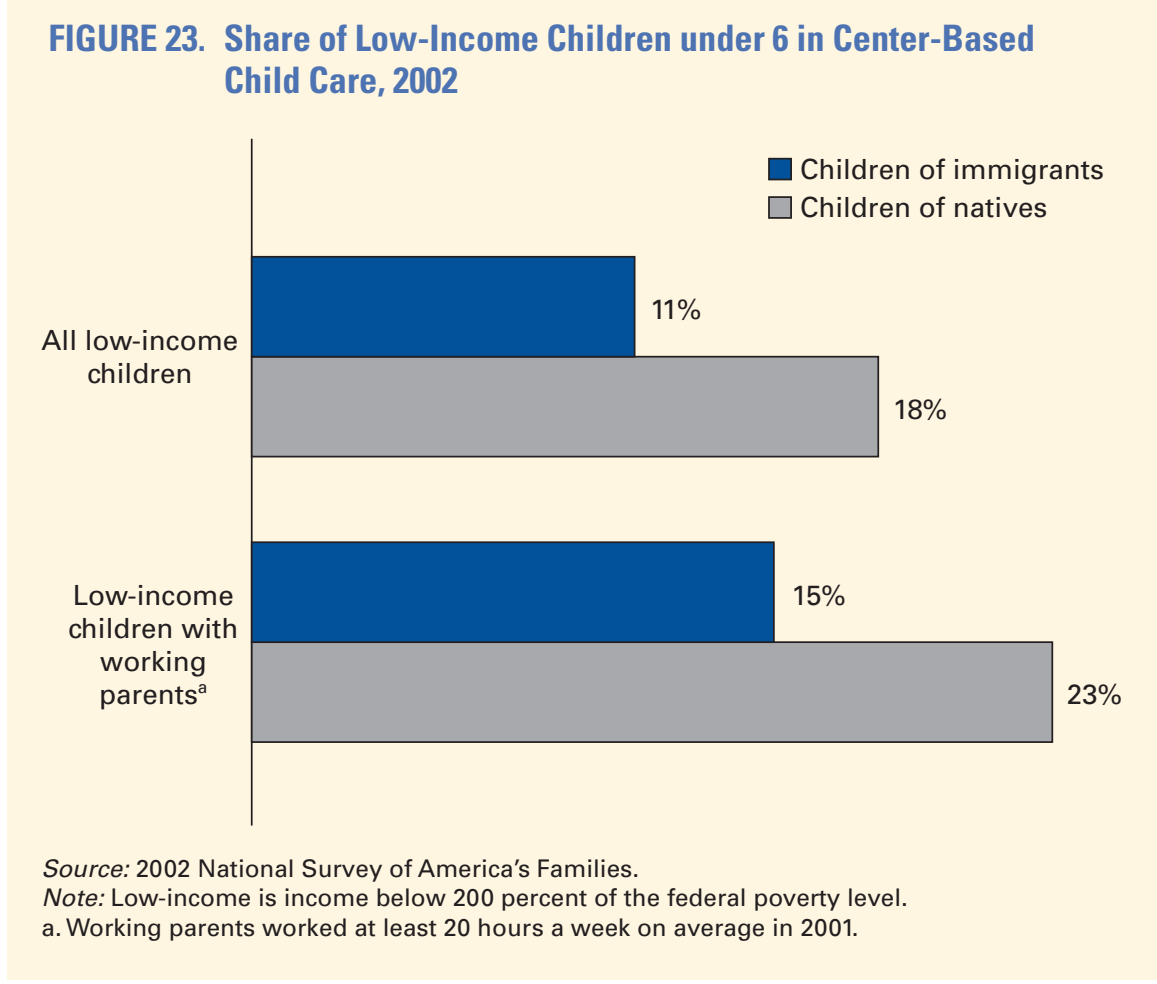

\section{Families with Two Working Parents Use Center-Based Care More Often, but Immigrant-Native Gap Remains}

Part of the explanation for the higher overall use of center-based care in native families lies in their higher shares with single and two working parents, when compared with immigrant families. Rates of center-based care enrollment are much higher for single-parent families and families with two working parents than for two-parent families where only one works, regardless of whether the parents are immigrants or natives. In two-parent families where only one parent works, 25 percent of young children in native families are enrolled in center-based care, versus 16 percent of children of immigrants (figure 24). By contrast, in single-parent families, 31 percent of children of natives are in center-based care, compared with only 20 percent of children of immigrants. Children with two working parents show similar center-based care enrollment rates: 30 percent for children of natives and 23 percent for children of immigrants. Thus, there is a significant gap in use of center-based care between children of immigrants and children of natives, regardless of family structure and parental work patterns.

\section{Center-Based Care More Common among Children Age 3 to 5, but Gap between Immigrants and Natives Persists}

The use of center-based care is much more common for preschool-age children 3-5 than for younger children age under age 3 (figure 25). Among children under 3, 15 percent in native families are in center-based care, a rate three times that for children of immigrants ( 5 percent). The disparity 
FIGURE 24. Share of Children under 6 in Center-Based Child Care by Family Structure and Parental Work, 2002

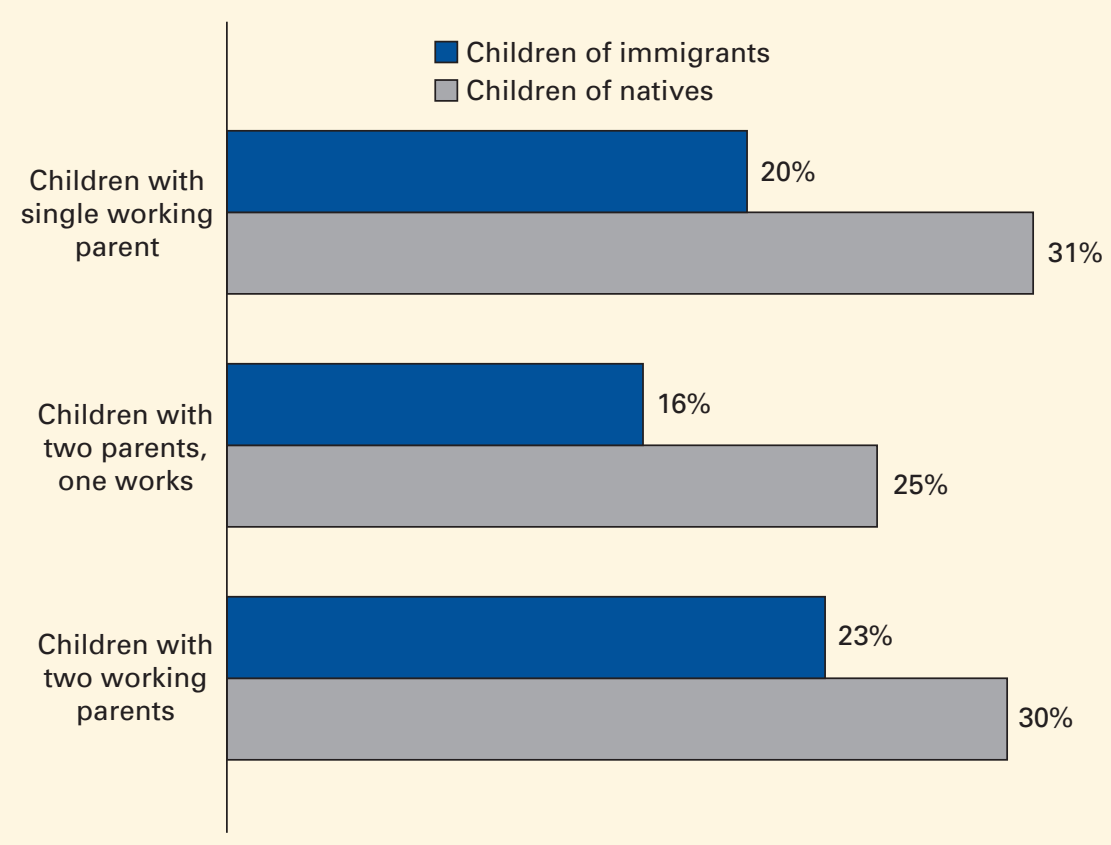

Source: 2002 National Survey of America's Families.

Note: Working parents worked at least 20 hours a week on average in 2001.

FIGURE 25. Share of Children in Center-Based Child Care by Age, 2002

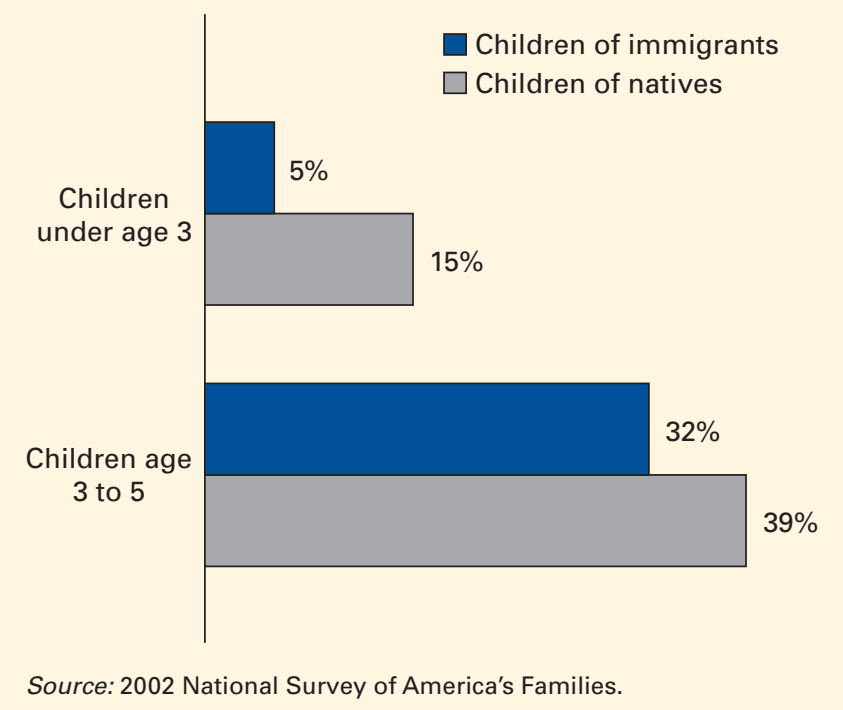


narrows for preschool-age children (age 3 to 5), but nonetheless a significant gap remains between children of natives (39 percent) and those of immigrants (32 percent).

\section{Center-Based Care Lowest in Least Educated Immigrant Families}

There is also a strong association between parental education and the share of children in center-based care. Among highly educated families, where at least one parent has completed four years of college, 33 percent of children of natives and 27 percent of children of immigrants are in center-based care (figure 26). By contrast, in the least educated families only 12 percent of children of natives and 5 percent of those of immigrants are in center-based care. Lower use of center-based care among children of immigrants is evident across all three parental education categories, however.

Both children of immigrants and children of natives whose parents have the lowest formal schooling are the least likely to be in center-based care. Parental education is also strongly associated with lower income and with less full-time work (Hernandez 2004), so these results may be driven partly by other factors. Yet the fact that such a small share (5 percent) of children of immigrants in the least educated families is enrolled in center-based care should be cause for concern, since the children in these families may have the greatest need for additional assistance in preparing for school, and quality child care centers have been found to promote school readiness (NICHD Early Child Care Research Network 2000).

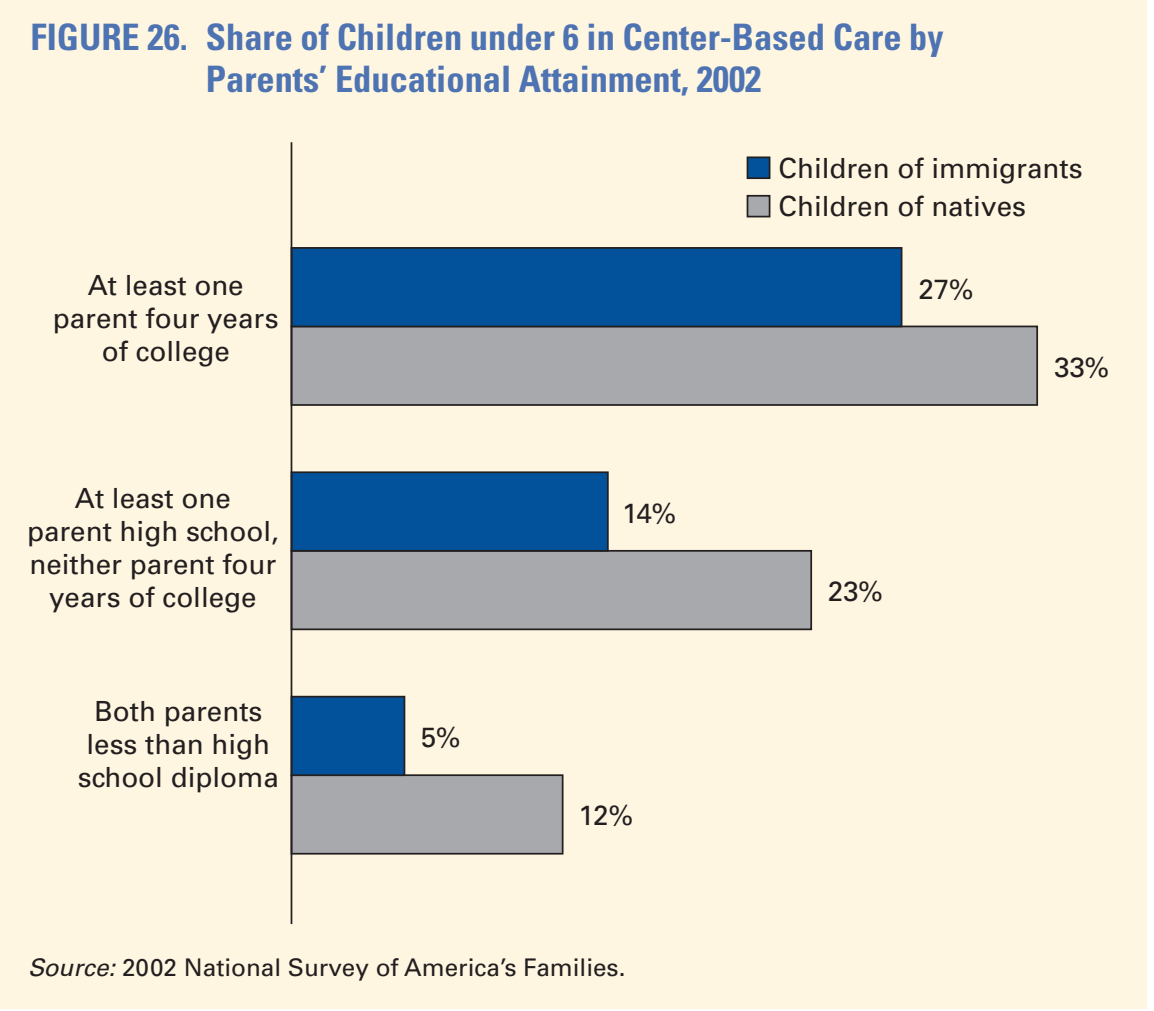




\section{Policy Implications}

These findings raise questions about whether child care arrangements are driven by parental choices or external constraints. While immigrant parents may choose not to use child care centers because they want family members caring for their children, their choices may also be driven by access barriers such as limited awareness of child care options, the high cost of care, unavailability of subsidies, inadequate space in nearby child care facilities, and legal status, language, and cultural barriers (Brandon 2004).

The quality of center-based child care may be uneven and not necessarily higher than that provided by other sources such as parents, relatives, or nannies/babysitters. There is evidence, though, that high-quality child care centers enhance school readiness, especially among children age 3 to 4 (NICHD Early Child Care Research Network 2000). As a result, lower use of centerbased care among children of immigrants, particularly those in low-income families, may slow the development of skills needed to prepare for school. That said, high-quality care may be achievable in other settings such as the homes of immigrants or other families. In fact, one strategy for improving school readiness may be to give immigrant parents and other child care providers additional resources (e.g., training, technical assistance, access to subsidies) to help them improve child developmental outcomes.

Beyond providing child care, many centers could deliver other public benefits and social services. For instance, child care centers could be sites for the delivery of food or emergency benefits, as well as referrals to community providers for housing, health care, job training, and other services. Centers are also possible locations for application assistance for public benefits programs such as TANF, food stamps, children's health insurance, and housing assistance. Some types of center-based care, Head Start for instance, already function as multiservice centers for lowincome children.

Finally, the exclusion of most recent legal immigrants from TANF_-along with declining TANF use rates among eligible legal immigrants_-holds implications for the enrollment of children of immigrants in child care. Reduced state budgets in the past several years have meant that child care subsidies are increasingly limited to only TANF recipients (Greenberg 2004). 


\section{CONCLUSIONS}

This report examines the demographics, family structure, poverty, hardship, health care, and child care arrangements of young children of immigrants. It offers several conclusions but also raises issues for further research. These issues include the following:

1. The well-being of young children in undocumented families. Although 93 percent of all young children of immigrants are U.S. citizens, 29 percent have one or more undocumented parents. The number of children with undocumented parents is likely to grow over time as undocumented immigration flows continue.

Undocumented immigrants generally earn less than legal immigrants or U.S. citizens (Capps et al. 2003), and undocumented immigrants are generally ineligible for public benefits and fearful of interacting with government agencies. So there is reason to believe that socioeconomic risk for young children with undocumented parents-in terms of poverty, hardship, health, and well-being-is high.

On one hand, these findings suggest that however Congress resolves the current debate over providing legal status for undocumented immigrants, the results will affect large numbers of immigrant families with young children. The findings also point out that we know little about the long-run consequences of having many children grow up in families with undocumented adults, and what the costs of doing so may be. (We are not aware of any substantial survey that has tracked the social and economic trajectories of children of undocumented immigrants who legalized under the 1986 Immigration Reform and Control Act.) Taken together, high numbers, high expected risks, and few data raise several key questions:

- How do income and poverty levels for young children in undocumented families compare to older children and children with legal immigrant and citizen parents? How do income and poverty vary by family structure and parental work-do the same patterns emerge as for children of immigrants overall?

- How do levels of food and housing hardship among children with undocumented parents compare to children with legal immigrant and citizen parents?

- What share of eligible children of undocumented immigrants are receiving such benefits as TANF and food stamps?

- What share of children of undocumented immigrants are uninsured? Covered by their parents' employers? Covered by Medicaid and SCHIP? What share of Medicaid- and SCHIPeligible children are covered? 
- Why do children with undocumented parents have lower insurance coverage and lower participation rates in public benefit programs? Are fears about or bad experiences with government agencies an important part of the story?

What are the patterns of enrollment in child care and early education programs?

What patterns are evident in school performance and grade promotion during the early years?

2. The well-being of young children whose parents lack English proficiency and formal education. Over one-quarter of young children of immigrants have parents who lack a high school education, and over half have parents who are limited English proficient. How do children in these families compare to children in English-proficient families on measures of income, poverty, hardship, and well-being? In their use of public benefits and enrollment in child care and preschool? In school performance? Our previous research in New York and Los Angeles (Capps et al. 2003) suggests that English proficiency among adults is the single most important determinant of poverty and food insecurity in immigrant families. Are these findings replicated nationally? What strategies can help immigrant families overcome these risk factors?

3. The relative influence of risk and protective factors on the well-being of young children of immigrants. Higher poverty, low parental education, and economic hardship represent risk factors for young children of immigrants. At the same time, the presence of two parents in the home and high levels of parental work represent important protective factors. How do these factors play out in determining child well-being? Do the associations between these factors and well-being differ significantly for young children of immigrants and those of natives? For younger and older children?

4. Reasons underlying the child care choices of immigrant parents. Young children of immigrants are significantly less likely to be in child care than young children of natives-especially center-based care-even when controlling for age, parental work, and income. Taken together, our findings on child care arrangements raise two central questions: (a) Why are children of immigrants generally less likely to be in any form of child care, except when they have two working parents? and (b) Why are children of immigrants enrolled in center-based care less often, regardless of parental income, educational attainment, and work? The answers to these questions have not been well researched and are not well understood (Takanishi 2004). A more detailed research agenda around child care for children of immigrants would address the following issues:

- Are there strong cultural reasons immigrant parents choose parental and other relative care over center-based care and other nonfamilial arrangements? Are immigrants less likely to use center-based care because they mistrust child care agencies and other community institutions? Do many immigrant women stay at home with children because of limited labor market opportunities?

- How does the legal status of parents—undocumented, legal immigrant, and citizen—affect child care choices?

- Do immigrant parents face child care access barriers - particularly for center-based caresuch as language, cultural misunderstandings, difficulty navigating the child care market, lack of available child care resources, insufficient income and public subsidies, and ineligibility or fear of interacting with providers because of legal status? What strategies are being used or could be used to lower these barriers? 
- How much do the cost of child care and availability of subsidies limit child care choices for immigrant parents? How high is the cost of child care relative to immigrants' family incomes? Are subsidies available to all legal immigrant parents, and do eligible immigrant parents participate in child care subsidy programs?

- Do child care choices influence the work patterns of immigrant mothers? If so, what are the implications for family income, poverty, and economic hardship? What strategies could be used to raise immigrant mothers' labor force participation and improve their earnings?

- How much do children of immigrants participate in different types of publicly funded center-based care, such as Head Start and school-based pre-kindergarten? What access barriers do immigrant parents face? What outreach programs are being undertaken or could be undertaken to enroll more children of immigrants in these programs?

\section{Defining a high-quality child care center or other setting for young children of immigrants.}

High-quality child care settings are important for the development of young children and their transition to formal schooling. Yet the meaning of "child care quality" has not been well defined for children in immigrant families.

- What are the outcomes (e.g., in terms of social development, language acquisition, and school readiness) for young children of immigrants in various center-based and other child care settings?

- Can child care centers be used to strengthen language acquisition and acculturation for children of immigrants? How segregated are child care centers, and how might segregation affect opportunities for contact among children from different ethnic and language backgrounds?

- Can center-based care help young children of immigrants overcome socioeconomic risks, such as poverty and low parental education? What model programs for children of immigrants exist?

van the characteristics of successful child care centers be transferred to other care settings - for instance, family-provided care- that might be more culturally appropriate for immigrants? 



\section{NOTES}

1. For consistency across data sources - the U.S. Census, U.S. Current Population Survey, and National Survey of America's Families — we consider only those parents residing with the child at the time of the survey.

2. These figures are based on the 1990 and 2000 U.S. Censuses of Population and Housing.

3. The data sources we use in this report include information about the place of birth and citizenship of adults and children. None of the data sources, however, directly report whether noncitizens are legal or undocumented (i.e., illegal). We have estimated the number of undocumented immigrants by taking the total number of noncitizens in the March 2002 Current Population Survey and subtracting our best estimate of how many are legal residents, using legal admissions data from the Department of Homeland Security. Once we obtained these estimates, we then assigned legal status (legal versus undocumented) to noncitizen adults in the CPS data using a variety of factors, including their age, country of birth, year of entry, and occupation. We then assigned legal status to noncitizen children based on the status of their parents (Passel and Clark 1998).

4. See, for example, S. 2381, The Safe, Orderly, Legal Visas and Enforcement Act of 2004.

5. Legal immigrant children are eligible for food stamps regardless of when they entered the United States. California and several other states with large immigrant populations use their own revenues to extend benefits similar to TANF and health insurance coverage similar to Medicaid to legal immigrants (adults and children in many states) regardless of when they entered the country (Zimmermann and Tumlin 1999).

6. Following Mexico, the next most common countries of birth for immigrant parents with young children are India (2.8 percent), Philippines (2.7 percent), Vietnam (2.4 percent), El Salvador (2.3 percent), Haiti (1.8 percent), Dominican Republic (1.5 percent), Guatemala (1.2 percent), Canada (1.2 percent), and China (1.2 percent).

7. Our definition of "work" includes parents who worked at least some time in the year before the survey.

8. This wage is calculated for the higher-earning parent, defined as the parent with more total earnings in the year before the survey (2001 for the 2002 CPS). We define "hourly wage" as total earnings divided by weeks worked and average hours worked in a week. We exclude families where neither parent has any earnings from these calculations.

9. In the text and figures this section, we calculate educational attainment for the better-educated parent.

10. In this analysis, we define "limited English proficient" as speaking a language other than English at home and speaking English less than "very well." The census asks which language is spoken at home for all individuals over age 5. For all those who speak a language other than English, the census asks whether they speak English "very well," "well," "not well," or "not at all." Among persons speaking another language at home, we classify all those who speak English "very well" as bilingual, and all others as LEP.

11. To gauge the need for food assistance, the NSAF asked adults whether they or their families worried that food would run out before they got money to buy more; the food they bought did run out; and one or more adults ate less or skipped meals because there was not enough money to pay for food.

12. The NSAF asked respondents whether the government pays their rent, they live in public housing, or an agency gave them a voucher to help pay rent. We defined families receiving housing assistance to be those answering "yes" to any of these three questions.

13. Legal immigrant adults are barred for five years from receiving TANF, food stamps, and Medicaid; undocumented immigrants are barred entirely.

14. To ascertain child health, the NSAF asks the adult most knowledgeable about the child whether the child's health is excellent, very good, good, fair, or poor. Since parents are reporting their subjective perceptions of the child's health, their responses could differ from more objective health measures provided by physical examinations, for instance. There may be some bias in the reporting of this measure, as the NSAF's sample of children of immigrants is heavily Latino, 
and Latinos tend to be more likely than other groups to report fair or poor health, even when they have similar outcomes on objective health measures (Shetterly et al. 1996).

NSAF's measure of health has been included in other national surveys — such as the CPS and National Health Interview Survey (NHIS). Results from the CPS and NHIS may differ from NSAF, perhaps because of the measure's subjectivity. To illustrate, using CPS data Hernandez (2004) finds similar disparities between children of natives and immigrants but much higher overall rates of children of all ages in fair or poor health: 17 percent for children of natives and 23 for children of immigrants.

15. The NSAF asks parents whether children usually go to a doctor's office, health clinic, hospital, or emergency room for health care. The indicator "no usual source of health care" excludes all these sites as primary sources of care.

16. The NSAF data show a 4 percentage point drop for children of immigrants, which is not statistically significant, most likely due to our small sample of young children of immigrants in each year. Since the 3 point drop for children of natives is significant and follows the same pattern, it seems likely that the drop for children of immigrants is also "real."

17. The NSAF data show a 5 percentage point drop for children of immigrants, which is not statistically significant, most likely due to our small sample of young children of immigrants in each year. Since the 4 point drop for children of natives is significant and follows the same pattern, it seems likely that the drop for children of immigrants is also "real."

18. Undocumented children are ineligible for Medicaid or SCHIP. They are generally ineligible for state and local health insurance programs as well, although in 2003 some California counties extended coverage to them. Some of the public coverage reported for children in the NSAF may represent Emergency Medicaid rather than regular Medicaid or SCHIP. Undocumented children are eligible for Emergency Medicaid, which is usually restricted to visits to hospital emergency rooms. There is concern among researchers that some people who receive emergency Medicaid may confuse it with the regular Medicaid and SCHIP programs. In other words, respondents may not understand precisely which forms of health care coverage they and their children have, and as a result may overreport enrollment in Medicaid and SCHIP.

19. In Florida, for instance, total KidCare enrollment — which includes Medicaid, SCHIP, and other programs-grew by nearly one-third from 1.1 million to 1.4 million between October 2000 and September 2002 (Florida KidCare 2003).

20. Despite concerns that state budget crises would reduce enrollment, Medicaid enrollment actually grew by 1.9 million, or 3.9 percent, nationally in 2003. Several states with large immigrant populations-including Florida, Massachusetts, New Jersey, Texas, and Washington — capped or reduced enrollment in Medicaid and SCHIP. Other administrative measures taken across the states may also slow growth or reduce enrollment in 2004. Colorado attempted to drop all legal immigrants from Medicaid, but was temporarily stopped by a court order (Holahan et al. 2004; see also Kaiser Family Foundation, "Medicaid Enrollment Grew by 1.6M People in 2003, According to CMS Data," Daily Health Policy Report, March 1, 2004, http://www.kaisernetwork.org/daily_reports/rep_hpolicy_recent_rep.cfm?dr_cat=3\& show=yes\&dr_DateTime=03-01-04\#22437).

21. This difference was not statistically significant, again mostly due to small sample size.

22. The Immigrant Children's Health Improvement Act (ICHIA), first introduced in the U.S. Congress in 2000, would restore Medicaid and SCHIP eligibility to legal immigrant children and pregnant women regardless of length of residency in the United States. Under current law, legal immigrants must be in the country for at least five years to be eligible, unless they are refugees or meet a few other limited exceptions. See National Immigration Law Center, "Background on Immigrant Children's Health Improvement Act," http://www.nilc.org/immspbs/health/health 009.htm.

The State Children's Health Insurance Program was amended in October 2002. The amendment changed the definition of "child" to include unborn children, thereby allowing states to use federal funding to provide prenatal care to women ineligible for Medicaid because of their lack of citizenship (i.e., because the unborn child is considered a U.S. citizen). See "State Children's Health Insurance Program: Eligibility for Prenatal Care and Other Health Services for Unborn Children,” Final Rule, 67 Federal Register 61956 (October 2, 2002).

23. We exclude 5-year-old children enrolled in school from the sample we use for the child care analyses in this section of the report because they spend a large share of their time during parents' working hours in school. We do not examine after-school child care arrangements for these children.

24. The child care arrangements referred to here are the primary forms of child care used by these families; families may also be using other forms of child care irregularly or less often.

25. Our definition of "center-based care" includes all these arrangements because the arrangement is reported by the parent or other adult most knowledgeable about the child, and parents do not always accurately distinguish among Head Start, pre-kindergarten, and other forms of center-based care.

26. Other studies have found relatively low participation among children of immigrants in center-based child care (Brandon 2004) and for Latinos in Head Start (Zambrana and Zoppi 2002), but participation in preschool for Asian Americans and Latinos as high as that for non-Hispanic whites (Smith et al. 2003).

27. Children with either a single parent or two parents who worked at least 20 hours apiece during the average week in the year before the survey (2001). 


\section{REFERENCES}

Brandon, Peter. 2004. "The Child Care Arrangements of Preschool-Age Children in Immigrant Families in the United States." International Migration 42:1.

Capizzano, Jeffrey, and Gina Adams. 2003. "Children in Low-Income Families Are Less Likely to Be in Center-Based Child Care.” Washington, DC: The Urban Institute. Snapshots of America's Families III No. 12.

Capps, Randy, Michael Fix, and Jeffrey S. Passel. 2002. "The Dispersal of Immigrants in the 1990s." Washington, DC: The Urban Institute. Immigrant Families and Workers: Facts and Perspectives Brief No. 2.

Capps, Randy, Jacqueline Hagan, and Nestor Rodriguez. 2004. "Border Residents Manage the U.S. Immigration and Welfare Reforms." In Immigrants, Welfare Reform, and the Poverty of Policy, edited by Phil Kretsedemas and Ana Aparicio. Westport, CT: Praeger.

Capps, Randy, Genevieve Kenney, and Michael Fix. 2003. "Health Insurance Coverage of Children in Mixed-Status Immigrant Families.” Washington, DC: The Urban Institute. Snapshots of America's Families III No. 16.

Capps, Randy, Michael Fix, Jeffrey S. Passel, Jason Ost, and Dan Perez-Lopez. 2003. "A Profile of the Low-Wage Immigrant Workforce." Washington, DC: The Urban Institute. Immigrant Families and Workers: Facts and Perspectives Brief No. 4.

Capps, Randy, Leighton Ku, Michael Fix, Chris Furgiuele, Jeffrey S. Passel, Rajeev Ramchand, Scott McNiven, and Dan Perez-Lopez. 2002. How Are Immigrants Faring After Welfare Reform? Preliminary Evidence from Los Angeles and New York City-Final Report. Washington, DC: The Urban Institute.

Cunnyngham, Karen. 2003. Trends in Food Stamp Program Participation Rates: 1999 to 2001. Washington, DC: Mathematica Policy Research, Inc. Available at http://www.fns.usda.gov/oane/MENU/Published/FSP/FILES/Participation/ Trends1999-2001.pdf.

Dubay, Lisa, Ian Hill, and Genevieve Kenney. 2002. "Five Things Everyone Should Know about SCHIP.” Washington, DC: The Urban Institute. Assessing the New Federalism Policy Brief A-55.

Fix, Michael, and Jeffrey S. Passel. 2002. "The Scope and Impact of Welfare Reform's Immigrant Provisions." Assessing the New Federalism Discussion Paper No. 02-03. Washington, DC: The Urban Institute.

Fix, Michael, and Wendy Zimmermann. 1999. All Under One Roof: Mixed-Status Families in an Era of Reform. Washington, DC: The Urban Institute.

Fix, Michael, Jeffrey S. Passel, and Kenneth Sucher. 2003. "Trends in Naturalization.” Washington, DC: The Urban Institute. Immigrant Families and Workers: Facts and Perspectives Brief No. 3.

Fix, Michael, Wendy Zimmermann, and Jeffrey S. Passel. 2001. The Integration of Immigrant Families in the United States. Washington, DC: The Urban Institute.

Florida KidCare. 2003. “State of Florida Children's Health Insurance Program: Annual Report to the Centers for Medicare and Medicaid Services, Federal Fiscal Year 2001-2002.” Tallahassee, Florida: Agency for Health Care Administration. http://www.fdhc.state.fl.us/Medicaid/MediKids/annual_report_2001_2002.pdf.

Fuligni, Andrew J., and Hirokazu Yoshikawa. 2003. "Socioeconomic Resources, Parenting, and Child Development among Immigrant Families." In Socioeconomic Status, Parenting, and Child Development, edited by Marc Bornstein and Robert Bradley (107-24). Mahwah, NJ: Lawrence Erlbaum.

Greenberg, Mark. 2004. "Welfare Reform, Phase Two: Doing Less with Less.” The American Prospect 15(9): A13.

Hernandez, Donald J. 1999. "Children of Immigrants: Health, Adjustment, and Public Assistance." In Children of Immigrants: Health, Adjustment, and Public Assistance, edited by Donald J. Hernandez (1-18). National Research Council and Institute of Medicine, Board on Children, Youth and Families, Committee on the Health and Adjustment of Immigrant Children and Families. Washington, DC: National Academy Press. 
. 2004. "Demographic Change and the Life Circumstances of Immigrant Families." New York: Foundation for Child Development. Available at http://fcd-us.org/uploadDocs/DJHPackard06_11_04.pdf.

Holahan, John, Teresa A. Coughlin, Randall R. Bovbjerg, Ian Hill, Barbara A. Ormond and Stephen Zuckerman. 2004. State Responses to 2004 Budget Crises: A Look at Ten States. Washington, DC: The Urban Institute.

Holcomb, Pamela, Karen C. Tumlin, Robin Koralek, Randy Capps, and Anita Zuberi. 2003. "The Application Process for TANF, Food Stamps, Medicaid and SCHIP: Issues for Agencies and Applicants, Including Immigrants and Limited English Speakers.” Washington, DC: The Urban Institute.

Kenney, Genevieve, Jennifer Haley, and Alexandra Tebay. 2003. "Children’s Insurance Coverage and Service Use Improve.” Washington, DC: The Urban Institute. Snapshots of America's Families III No. 1.

National Center for Children in Poverty. 2002. Children of Immigrants in the United States Are Growing in Number and Facing Substantial Economic Hardship. New York: National Center for Children in Poverty.

National Institute of Child Health and Human Development Early Child Care Research Network. 1999. "Child Outcomes When Child Care Center Classes Meet Recommended Standards for Quality.” American Journal of Public Health 89(7): 1072-77.

- 2000. "The Relation of Child Care to Cognitive and Language Development." Child Development 71(4): 960-80.

National Research Council and Institute of Medicine. 1999. From Generation to Generation: The Health and Well-Being of Children in Immigrant Families, edited by Donald J. Hernandez and Evan Charney. Board on Children, Youth, and Families, Committee on the Health and Adjustment of Immigrant Children and Families. Washington, DC: National Academy Press.

- 2000. From Neurons to Neighborhoods: The Science of Early Child Development, edited by Jack P. Shonkoff and Deborah A. Phillips. Board on Children, Youth, and Families, Commission on Behavioral and Social Sciences and Education, Committee on Integrating the Science of Early Childhood Development. Washington, DC: National Academy Press.

Passel, Jeffrey S., and Rebecca Clark. 1998. "Immigrants in New York: Their Legal Status, Incomes, and Taxes." Washington, DC: The Urban Institute.

Phillips, Deborah A. 2001. Testimony to the Committee on Education and the Workforce, U.S. House of Representatives, Washington, D.C., July 31.

Reardon-Anderson, Jane, Randy Capps, and Michael Fix. 2002. "The Health and Well-Being of Children in Immigrant Families." Washington, DC: The Urban Institute. Assessing the New Federalism Policy Brief B-52.

Reed, Deborah, and Amanda Bailey. 2002. "California's Young Children: Demographic, Social, and Economic Conditions.” California Counts 4(2). San Francisco: The Public Policy Institute of California.

Rodriguez, Nestor, Jacqueline Hagan, and Randy Capps. 2004. "The Effects of Recent Welfare and Immigration Reforms on Immigrants' Access to Health Care." International Migration Review 38:2.

Shetterly, S.M., J. Baxter, L.D. Mason, and R.F. Hamman. 1996. "Self-Rated Health among Hispanic vs. Non-Hispanic White Adults: The San Luis Valley Health and Aging Study.” American Journal of Public Health 86(12): 1798-1801.

Smith, Timothy, Anne Kleiner, Basmat Parsad, and Elizabeth Farris. 2003. Prekindergarten in U.S. Public Schools: 2000-2001. Statistical Analysis Report. NCES 2003-019. Washington, DC: National Center for Education Statistics. Available at http://nces.ed.gov/pubs2003/2003019.pdf.

Takanishi, Ruby. 2004. "Leveling the Playing Field: Supporting Immigrant Children from Birth to Eight." New York: Foundation for Child Development. Available at http://fcd-us.org/uploadDocs/RTPackard06_11_04.pdf.

Vandivere, Sharon, Kristin Moore, and Brett Brown. 2000. "Child Well-Being at the Outset of Welfare Reform: An Overview of the Nation and 13 States." Washington, DC: The Urban Institute. Assessing the New Federalism Policy Brief B-23.

Zambrana, Enid, and Irene M Zoppi. 2002. "Latino Students: Translating Cultural Wealth into Social Capital to Improve Academic Success.” Journal of Ethnic and Cultural Diversity in Social Work 11(1/2): 33-53.

Zimmermann, Wendy, and Michael Fix. 1998. "Declining Applications for Medi-Cal and Welfare Benefits in Low Angeles County." Washington, DC: The Urban Institute. Immigration Studies paper.

Zimmermann, Wendy, and Karen Tumlin. 1999. Patchwork Policies: State Assistance for Immigrants under Welfare Reform. Washington, DC: The Urban Institute. Assessing the New Federalism Occasional Paper No. 24. 



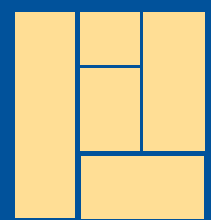

\section{Urban}

\section{Institute}

2100 M Street, NW

Washington, DC 20037

Phone: 202.833.7200

Fax: 202.429.0687

E-mail: paffairs@ui.urban.org

http://www.urban.org 